\title{
Extended Spectrum $\beta$-Lactamase (ESBL) Producing Escherichia coli in Pigs and Pork Meat in the European Union
}

\author{
Ieva Bergšpica ${ }^{1,2, *}$, Georgia Kaprou ${ }^{1}\left(\mathbb{D}\right.$, Elena A. Alexa ${ }^{1}\left(\mathbb{D}\right.$, Miguel Prieto $^{1,3}{ }^{(\mathbb{D}}$ and \\ Avelino Alvarez-Ordóñez ${ }^{1,3, *}$ \\ 1 Department of Food Hygiene and Technology, Universidad de León, 24007 León, Spain; \\ gdkaprou@gmail.com (G.K.); ealexandra.alexa@gmail.com (E.A.A.); miguel.prieto@unileon.es (M.P.) \\ 2 Institute of Food Safety, Animal Health and Environment BIOR, LV-1076 Riga, Latvia \\ 3 Institute of Food Science and Technology, Universidad de León, 24007 León, Spain \\ * Correspondence: ieva.bergspica@bior.lv (I.B.); aalvo@unileon.es (A.A.-O.)
}

Received: 10 September 2020; Accepted: 3 October 2020; Published: 7 October 2020

check for updates

\begin{abstract}
The aim of this article is to review the fast and worldwide distribution of ESBL enzymes and to describe the role of the pork production chain as a reservoir and transmission route of ESBL-producing Escherichia coli and ESBLs in the European Union (EU). The use of $\beta$-lactam antibiotics in swine production and the prevalence of ESBL producing E. coli in fattening pigs and pork meat across Europe is analyzed. Overall, an increasing trend in the prevalence of presumptive ESBL producing E. coli in fattening pigs in the EU has been observed in the last decade, although with major differences among countries, linked to different approaches in the use of antimicrobials in pork production within the EU. Moreover, the various dissemination pathways of these bacteria along the pork production chain are described, along with factors at farm and slaughterhouse level influencing the risk of introducing or spreading ESBL producing bacteria throughout the food chain.
\end{abstract}

Keywords: ESBL; E. coli; prevalence; pigs; pork meat; EU

\section{Introduction}

Antimicrobial resistance (AMR) is a global concern in public health, threatening to complicate the treatment of infections worldwide. Emergence and spread of AMR has been attributed to the misuse or overuse of antibiotics in human and veterinary medicine. Antimicrobial resistance occurs as microorganisms modify their genetic information when they are exposed to antimicrobial drugs [1].

The use of antibiotics dates back to the beginning of the 20th century, when Paul Ehrlich discovered a chemical called arsphenamine which was effective against Treponema pallidum, the bacterium causing syphilis [2]. Twenty years later, in 1928, Alexander Fleming isolated penicillin, a $\beta$-lactam antibiotic from the fungus Penicillium notatum and, since then, the strike of the antibiotic's era began.

$\beta$-lactams, such as penicillins, carbapenems, monobactams, and cephalosporins account for $60 \%$ (by weight) of all antibiotics used worldwide, and in human medicine are one of the most widely prescribed antibiotic classes [3,4]. Intensive use and misuse of $\beta$-lactam antibiotics both in human and in veterinary medicine has led to the spread of extended spectrum $\beta$-lactamase (ESBL) producing resistant bacteria. The World Health Organization (WHO) has indicated that third generation resistant Enterobacteriaceae, including ESBL-producing Enterobacteriaceae, are among the world's most serious and critical threats of the 21st century [5].

$\beta$-lactams interfere with the synthesis of the bacterial cell wall, which results in the inhibition of bacterial growth, by binding to penicillin-binding-proteins (PBPs) that are enzymes involved in 
the synthesis of peptidoglycan. $\beta$-lactam antibiotics are used to treat infections caused by both Gram-positive and Gram-negative bacteria. They all share as a common structure a four-membered lactam ring, known as the $\beta$-lactam ring (Figure 1). This is a cyclic amide with a heteroatomic ring structure that consists of three carbon atoms and one nitrogen atom [6]. $\beta$-lactam antibiotics act on the formation of the bacterial cell wall by interfering with the PBPs at the final stage of peptidoglycan synthesis [6].

The intensive use of $\beta$-lactam antibiotics for the past 70 years has led to the evolution of $\beta$-lactam resistance in bacteria. Resistance against $\beta$-lactam antibiotics in bacteria can be ensured through three different mechanisms. The first mechanism includes the mutation in genes encoding for PBPs, the creation of mosaic PBPs or obtaining alternative PBPs [6]. The second mechanism consists of changes in the permeability of the cell wall that could be due to alterations in the expression of porins or active efflux pumps [6]. However, the most frequent mechanism is the third one-the inactivation of the antibiotic by the expression of $\beta$-lactamases [6].

The first $\beta$-lactamases were discovered in 1940 by Edward Penley Abraham [7]. $\beta$-lactamases are enzymes produced by bacteria that inactivate the $\beta$-lactam ring by breaking the amide bond of the $\beta$-lactam ring and adding a water molecule to the ring-opened molecule. Narrow spectrum $\beta$-lactamases are also called penicillinases or cephalosporinases, depending on the target. Moreover, some Gram-negative bacteria, especially members of the Enterobacteriaceae family, and Gram-positive bacteria, e.g., Staphylococcus aureus, can also produce an array of extended spectrum $\beta$-lactamases (ESBLs), enzymes that hydrolyze many different $\beta$-lactams and can cause resistance to oxyimino-cephalosporins (cefotaxime, ceftazidime, ceftriaxone, cefuroxime, cefepime) and monobactams (aztreonam), but not to cephamycins (cefoxitin, cefotetan) or carbapenems (imipenem, meropenem, ertapenem, doripenem) [8-10]. ESBLs are inhibited by ESBL inhibitors, such as clavulanate, sulbactam and tazobactam (older $\beta$-lactamase inhibitors) and avibactam, relebactam and vaborbactam (latest Food and Drug Administration (FDA)-approved inhibitors), which are therefore frequently included with $\beta$-lactam antibiotics in the formulation of therapeutic drugs [11].
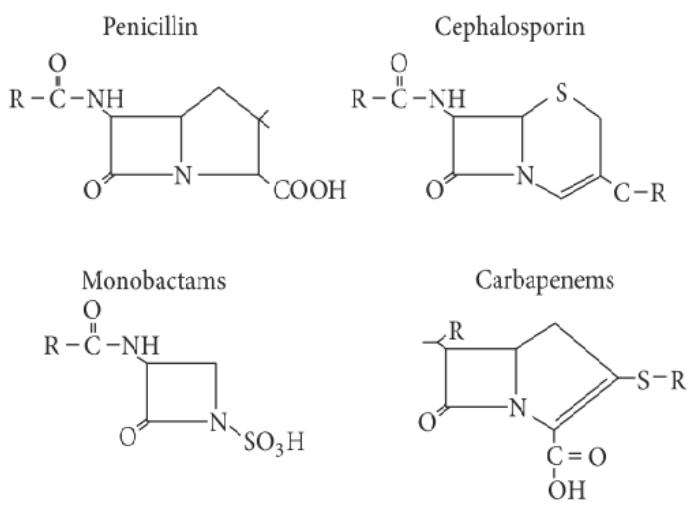

Figure 1. Structure of $\beta$-lactam antibiotics, adapted from [12].

As $\beta$-lactamases share some sequence homology with PBPs, it is considered that they have evolved from them $[10,13]$. $\beta$-lactamase encoding genes (bla) can be located in chromosomes or plasmids. The first plasmid-mediated $\beta$-lactamase (TEM-1) in Gram-negatives was described in 1965, from an isolate from a patient named Temoniera in Greece, therefore named TEM [14]. Since then, hundreds of different $\beta$-lactamases have been discovered, and the first ESBL (SHV-2) was discovered in Germany, isolated from a Klebsiella ozonae strain in 1985 [15]. The CTX-1 enzyme was discovered in 1985 from Klebsiella pneumoniae, isolated from patients in an intensive care unit in France [16]. Nowadays, it is the most widely spread $\beta$-lactamase in food-producing animals [17].

According to the reports of the European Food Safety Authority (EFSA) the prevalence of presumptive ESBL producing E. coli in fattening pigs and pork meat varies a lot within the EU countries $[18,19]$. It is worth noting that there are several steps within the pork production chain where 
pigs are exposed to ESBL producing bacteria and can become carriers of them, such as trading places, where new animals are mixed with older animals within the same herd, or slaughterhouse waiting areas [20]. In addition, cross-contamination in slaughterhouses, especially at evisceration, poses a risk of carcass contamination with ESBL producing Enterobacteriaceae [21,22]. This review article is aimed at discussing and analyzing aspects related to the occurrence and transmission routes of ESBL producing Enterobacteriaceae in the pork production chain.

\section{Classification of ESBLs}

The number of ESBLs reported is constantly growing [12]. They are subdivided into ten families based on their amino acid sequences-CTX-M, TEM, SHV, SFO, PER, VEB, GES, TLA, BES and OXA. In this review article the focus will be on CTX-M, TEM and SHV ESBLs as they are the most common among members of the Enterobacteriaceae family. There are two main characterization schemes of $\beta$-lactamases-the Ambler's scheme and the Bush-Jacoby-Medeiros scheme [23,24]. The Bush-Jacoby-Medeiros classification, which is based on functional similarities among $\beta$-lactamases (i.e., substrate and inhibitor profile), recognizes a total of 11 groups to classify $\beta$-lactamases. Extended-spectrum $\beta$-lactamases are assigned to group 2 be if the hydrolysis rates for ceftazidime, cefotaxime or aztreonam are by $10 \%$ higher than for benzylpenicillin [24]. According to the Ambler's classification, $\beta$-lactamases are subdivided in four classes (A-D) [23]. These classes differ in their mechanisms of action and active sites. Class A, C, and D $\beta$-lactamases have serine at their active sites and undertake hydrolysis of serine esters, while class B $\beta$-lactamases have zinc ion(s) at their active site, catalyzing the hydrolysis of almost all $\beta$-lactam antibiotics, with the exception of monobactams $[25,26]$. There are more than 500 enzymes that belong to the class A of $\beta$-lactamases, including the ESBL variant TEM, CTX-M, and SHV enzymes (Table 1).

Table 1. Classification of TEM, SHV and CTX-M $\beta$-lactamases. Adapted from [27].

\begin{tabular}{|c|c|c|c|c|c|c|c|}
\hline$\beta$-Lactamase & $\begin{array}{l}\text { Molecular Weight of } \\
\text { the Enzyme }\end{array}$ & $\begin{array}{l}\text { Bush-Jacoby } \\
\text { Medeiros } \\
\text { Class }\end{array}$ & $\begin{array}{l}\text { Ambler } \\
\text { Class }\end{array}$ & $\begin{array}{l}\text { Active } \\
\text { Site }\end{array}$ & $\begin{array}{l}\text { Preferential } \\
\text { Substrate }\end{array}$ & Gene & Organisms \\
\hline TEM & \multirow[t]{3}{*}{$\sim 29,000 \mathrm{Da}$} & \multirow[t]{3}{*}{$2 \mathrm{be}$} & \multirow[t]{3}{*}{ A } & \multirow[t]{3}{*}{ Serine } & \multirow{3}{*}{$\begin{array}{l}\text { Penicillins } \\
\text { and } \\
\text { 1st-4th } \\
\text { generation } \\
\text { cephalosporins }\end{array}$} & \multirow[t]{3}{*}{$\mathrm{Pl}^{*}$} & $\begin{array}{l}\text { Enterobacteriaceae, } \\
\text { Haemophilus influenzae, } \\
\text { Neisseria gonorrhoeae, } \\
\text { Pseudomonas aeruginosa }\end{array}$ \\
\hline SHV & & & & & & & Enterobacteriaceae \\
\hline CTX-M & & & & & & & Enterobacteriaceae \\
\hline
\end{tabular}

${ }^{*} \mathrm{Pl}$-plasmid mediated.

Apart from TEM, CTX-M and SHV ESBLs, there are other ESBLs which are not so common among members of the family Enterobacteriaceae and will not be covered in this review article, like PER-1 $\beta$-lactamases, which confer resistance to ceftazidime in Acinetobacter baumanii and Pseudomonas aeruginosa [28]; FEC and SFO ESBLs, which hydrolyze cefotaxime [29,30]; GES, CME and PER ESBLs, which hydrolyze ceftazidime [31-33]; BES and TLA $\beta$-lactamases, which can hydrolyze several substrates, like cefotaxime, ceftazidime and aztreonam [34,35], and OXA $\beta$-lactamases, which hydrolyze oxacillin and cloxacillin and are poorly inhibited by clavulanic acid. Even though most of the OXA-type $\beta$-lactamases do not hydrolyze extended spectrum cephalosporins, there are some exceptions. In 1991, the first ESBL-type OXA (OXA-11) enzyme, deriving from OXA-10, was recovered from a $P$. aeruginosa isolate which showed resistance to ceftazidime. Apart from the OXA-11 enzyme, several other ESBLs have derived from OXA-10 as well, such as OXA-13, OXA-14 [36], OXA-16 [37], OXA-17 [38], OXA-19 [39] and OXA-28 [40]. The OXA-15 enzyme, which derives from OXA-2 $\beta$-lactamases, also confers an ESBL phenotype [41]. ESBL OXA-type enzymes are mostly found in $P$. aeruginosa and have hardly been identified in other species, which indicates a probable low transfer rate between species [42]. 
Two main strategies for the evolution of ESBLs have been identified in Enterobacteriaceae: (i) the selection of mutants that have a wider spectrum of substrate hydrolysis and are derived from plasmid-mediated TEM and SHV type $\beta$-lactamases; and (ii) the acquisition from the environment of novel $\beta$-lactamase genes that encode ESBL enzymes [43].

TEM-type $\beta$-lactamases are responsible for ampicillin resistance among Enterobacteriaceae [44]. TEM-1 $\beta$-lactamases are plasmid- and transposon-mediated. This location has facilitated their spread to other bacterial species worldwide. They can be found in different members of the family Enterobacteriaceae, and in P. aeruginosa, Haemophilus influenzae and Neisseria gonorrheae [10]. Several hundred variants of TEM $\beta$-lactamases have been described and all of them have derived from TEM-1 and TEM-2 $\beta$-lactamases [45]. Single nucleotide polymorphisms (SNPs) in $b l a_{\mathrm{TEM}}$ genes, which encode TEM $\beta$-lactamases, may lead to amino acid substitutions in the enzyme. The most common substitutions are those at the $\mathrm{Glu}^{104}$, $\mathrm{Arg}^{164}$, $\mathrm{Glu}^{238}$ and $\mathrm{Glu}^{240}$ positions [46]. The majority of TEM $\beta$-lactamases are ESBLs. Some of the TEM derivates have reduced affinity for $\beta$-lactamase inhibitors and are called inhibitor-resistant TEM. They also have negligible activity against extended-spectrum cephalosporins, and therefore they are not considered as ESBLs [6].

The probable ancestor of the enzyme SHV (sulfhydryl reagent variable) is a chromosomal penicillinase of Klebsiella pneumoniae. The first ESBL SHV enzyme was isolated from Klebsiella ozaenae in 1983, and, since then, various SHV types responsible for resistance to third generation cephalosporins have been described [15]. SHV $\beta$-lactamases can be subdivided into three subgroups based on their molecular characteristics or functional properties. Members of the subgroup $2 b$ hydrolyze penicillins and early generation cephalosporins, and are inhibited by clavulanic acid and tazobactam; members of the subgroup $2 \mathrm{br}$ are broad-spectrum $\beta$-lactamases that are resistant to clavulanic acid; and members of the subgroup 2 be hydrolyze one or more oxyimino $\beta$-lactams (ceftazidime, cefotaxime, and aztreonam) [47]. There are over one hundred allelic variants of SHV $\beta$-lactamases described [45]. Many of those are associated with resistance to third generation cephalosporins as well as monobactam and carbapenems [48].

Broad-spectrum SHV-1 $\beta$-lactamases dominate in K. pneumoniae and are responsible for up to $20 \%$ of plasmid-mediated ampicillin resistance in this species [49]. SHV enzymes can be found in different species, such as Enterobacter cloacae, Salmonella, K. ozaenae, Citrobacter freundii but more commonly in K. pneumoniae and E. coli. They are usually chromosomally encoded in K. pneumoniae, and plasmid-encoded in E. coli [10]. Some variants of SHV $\beta$-lactamases (e.g., bla ${ }_{\mathrm{SHV}-27}$ ) have been found on plasmids simultaneously carrying several ESBL coding genes [47].

The active site of SHV $\beta$-lactamases is located within a cleft made by subdomains and contains a $\mathrm{Ser}^{70}$ residue that mediates the nucleophilic attack on the carbonyl group of the $\beta$-lactams ring [47]. ESBL SHV enzymes, compared to SHV-1, have one to six amino acid substitutions, what means that even single amino acid changes can lead to an ESBL phenotype. The most common substitutions are at $\mathrm{Leu}^{35}$, Gly ${ }^{238}$ and Glu ${ }^{240}$ positions [47]. Plasmid-borne SHV enzymes are commonly found in bacteria isolated from food producing animals and meat products [47].

The bla $_{\mathrm{SHV}-1}$ gene was first identified in 1970s in E. coli [50]. Until now, there are over $180 \mathrm{SHV}$ allelic variants characterized. At least 46 of those are ESBL SHV encoding bla $a_{\mathrm{SHV}}$ genes, and most of them have been detected in E. coli or K. pneumoniae [47]. Probably, SHV ESBLs have evolved from $b l a_{\mathrm{SHV}-11}$ and $b l a_{\mathrm{SHV}-1}$ genes [47]. SHV ESBLs have been described worldwide, most of them are associated with plasmids and have been reported as unique cases.

CTX-M-type $\beta$-lactamases hydrolyze cefotaxime, and there are over 220 different CTX-M-type enzymes characterised so far. CTX-M $\beta$-lactamases are widely disseminated within Enterobacteriaceae, e.g., E. coli, S. enterica, C. freundii, Proteus mirabilis, E. cloacae, K. pneumoniae, Morganella morganii, Providencia spp., etc. [51-53]. However, CTX-M-type ESBLs have also been identified in some species apart from Enterobacteriaceae, such as Pseudomonas aeruginosa, Acinetobacter spp., Aeromonas spp., Stenotrophomonas maltophillia, Vibrio fluvialis and Vibrio cholerae, indicating a high transmission rate of CTX-M-type genes [43]. bla 
mainly carried by conjugative plasmids, although in some species bla $a_{\mathrm{CTX}-\mathrm{M}}$ genes are integrated into chromosomes [43,54]. Olson and colleagues discovered in 2005 that the ancestor of the CTX-M-9 group of ESBLs is a chromosomal $\beta$-lactamase from $K$. georgiana [55]. CTX-M $\beta$-lactamases hydrolyze cefotaxime and ceftriaxone better than ceftazidime. However, the spectrum of hydrolysis varies by the enzyme, and there are CTX enzymes (CTX-M-15, CTXM-16 and CTX-M19) that exhibit enhanced catalytic efficiencies against ceftazidime $[11,56]$.

CTX-M-type enzymes are susceptible to $\beta$-lactamase inhibitors (e.g., tazobactam and clavulanate) as well as to the new non $\beta$-lactam-derived $\beta$-lactamase inhibitor avibactam [57]. Since the first sporadic cases of CTX-M producing bacteria in the 1980s in Europe [58], Japan [29] and South America [59], the CTX-M-type ESBLs have outnumbered other ESBLs, such as TEM and SHV [43] and have become the most common type of ESBL [4]. The rapid spread of CTX-M- type ESBLs depends on many factors, such as the effective capture and dissemination of bla $a_{\text {СТХ-M }}$ genes on mobile genetic elements (MGEs), the association of MGEs with highly successful bacterial clones, the low fitness cost imposed by CTX-M production, and the intensive use of expanded-spectrum cephalosporins and fluoroquinolones (which can co-select CTX-M-producing strains that are often resistant also to these drugs) in veterinary and clinical fields [43].

In 1990s the most frequently found ESBL genes were $b l a_{\mathrm{TEM}}$ and $b l a_{\mathrm{SHV}}$, but nowadays the most prevalent genes in livestock are bla ${ }_{\text {CTX-M }}[17,60]$. There are hundreds of variants of CTX-M genes identified and they show higher activity against cefotaxime than against other oxyimino- $\beta$-lactams [9].

\section{Dissemination of ESBLs}

\subsection{Dissemination Pathways of Antibiotic Resistance Genes}

Many of the $\beta$-lactamase encoding resistance genes are believed to be originated from non-pathogenic bacteria [61]. Some bacteria are natural hosts of $\beta$-lactamases, such as Streptomyces, Nocardia, and Actinomadura [27]. However, other bacteria, including E. coli, can gain resistance genes via horizontal gene transfer (HGT) between bacteria belonging to the same or even different species [61,62]. Transfer of bla encoding genes can occur through different pathways, for example, vertical proliferation of bacteria or HGT via MGEs, that include transposons, integrons, insertion sequences (IS), plasmids or bacteriophages.

HGT can be carried out via transformation, conjugation or transduction. Transformation is a process where competent cells uptake plasmid DNA or chromosomal DNA fragments that have been released to the extracellular environment after the cell death [63]. Conjugation is the transfer of DNA through direct contact via cell surface pili or adhesins [61]. However, transduction requires additional organisms to transmit the genetic information. Indeed, in transduction, bacteriophages replicate within the donor organism and, at DNA packaging, sometimes incorporate DNA sequences from the host cell into a new host [61].

Plasmids can be mobilized in the same or different species, via conjugation. One bacterium can carry several plasmids encoding different antibiotic resistance genes (ARGs), depending on plasmid incompatibility (Inc). Incompatibility is a manifestation of the relatedness of plasmids. Therefore, compatible plasmids can survive together in transconjugants, but plasmids that are related will not be stably propagated together [54]. The bla ESBL coding genes, e.g., bla $a_{\mathrm{TEM}-1}$ and bla $a_{\mathrm{OXA}-1}$ [54]. The dissemination of $b l a_{\mathrm{CTX}-\mathrm{M}}$ within members of the Enterobacteriaceae has been rapid due to its capability to be transferred by all major Inc plasmids, e.g., bla $a_{\mathrm{CTX}-\mathrm{M} 14}$ is frequently associated with IncK plasmids $[43,64]$, and it has been shown that Incl1 ST3 plasmids are a frequent vector for the dissemination of CTX-M-1 $\beta$-lactamases within food products of animal origin [17]. It has also been demonstrated that the ISEcp1 element and conjugative plasmids have facilitated the transfer of CTX-M genes to different species [65]. More information on the most prevalent and studied plasmids in the Enterobacteriaceae family can be found in Carattoli et al. [54]. 
Transposons can transfer resistance genes between plasmids, or into and out of the chromosome. $b l a_{\text {TEM }}$ genes are carried by three transposons, Tn1, Tn2 and Tn3, respectively. All these transposons have transposase and resolvase genes, $\operatorname{tnpA}$ and $\operatorname{tnpR}$, and a res resolution site [6]. Similarly, as bla $a_{\mathrm{SHV}}$ originated from a K. pneumoniae chromosome, fragments of this chromosome together with the bla $a_{\mathrm{SHV}}$ gene have been carried to plasmids by IS26-dependent mobilization.

Insertion sequences (ISs) are transposable elements responsible for the mobilization and transfer of ARGs. Some ISs, such as ISCR1, take part in the transmission of $\beta$-lactamase coding genes, ESBLs included [66]. Indeed, ISEcp1B and ISCR1 play a major role in the transmission of the

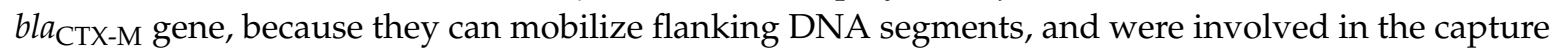
of CTX-M genes from the Kluyvera spp. chromosome and their transposition to plasmids $[66,67]$. Also phage-related elements take part in the dissemination of the $b l a_{\mathrm{CTX}-\mathrm{M}}$ gene within members of the Familiy Enterobacteriaceae [68].

An integron is a genetic unit able to capture, mobilize and express genes that are contained in genetic elements known as gene cassettes [69]. Multidrug resistance is strongly associated with the presence of integrons, as they commonly carry a large array of resistance gene cassettes [70,71]. Yuan and colleagues highlighted that highly active ARG transfer might occur via class 1 integrons between E. coli and other bacteria, while Poirel et al. [72] showed that the mobilization of bla genes is associated with class I integrons [73].

\subsection{Dissemination of ESBL-Producing E. coli in the Pork Production Chain}

E. coli is a component of the normal human and animal gut microbiota. This feature makes E. coli one of the most probable vectors for the spread of ESBLs [74]. As explained in previous sections, the wide spread of ESBLs is ensured by plasmids and other MGEs [54].

An interesting example of transfer from food-producing animals to the human gut microbiome is Escherichia coli ST131, which is an extraintestinal pathogen which can colonize the gastrointestinal tract of food-producing animals and humans [75]. This sequence type of E. coli was believed to be selected in poultry during the 1940s and, since then, has been recognized as a vehicle for human exposure and infection [76]. Interestingly, it often carries different plasmids (sometimes also encoding ARGs) and has contributed to the dissemination of CTX-M $\beta$-lactamase encoding genes, and, less frequently, TEM, SHV and cephalomycinase (CMY) encoding genes [77].

High correlations exist between resistance profiles of $E$. coli isolated from food animals, like poultry and pigs, and those of isolates from humans with blood stream infections [78]. In addition, it has been shown that genetically distinct E. coli isolates from humans and animals carry nearly identical IncI1 plasmids that encode third-generation cephalosporin resistance determinants and probably contribute to the spread of ESBLs through food animals (e.g., pork, chicken) to humans [79].

Some of the initial phases where pigs can be colonized by ESBL-producing E. coli is at trading places, livestock transport vehicles, through introduction of new animals into herds, or at lairage in the slaughterhouse [20]. As drinking water [80], surface water [81] and wastewater [82], all can be contaminated with ESBL-producing E. coli, a possible transmission of ESBLs from the environment to pigs can occur. Holding pens in stables and at lairage in abattoirs are recognized as major hotspots for the transmission of ESBL producing Enterobacteriaceae along the pig production chain [83].

At slaughterhouses, a risk of cross-contamination of meat exists, especially during evisceration, where carcasses can be contaminated by AMR bacteria from the feacal content of the same or different pigs [21,22]. Food processing environments are considered to be important intermediate reservoirs and vectors of AMR bacteria, and also food handlers pose a risk of transmission of ESBL producing bacteria $[84,85]$.

By performing whole-genome sequencing (WGS) to ESBL producing E. coli isolates obtained from farmers, poultry and pigs, an association was made between the isolates from farmers and pigs, as they showed only 1.8 single nucleotide polymorphism (SNP) mismatches per $1 \mathrm{Mb}$, but no association was established between isolates from humans and poultry as the SNPs per $1 \mathrm{Mb}$ were in 
1263 positions [79]. These data suggested that transfer of ESBL-producing E. coli clones between pigs and piggery workers occurs.

\section{Use of $\beta$-Lactam Antibiotics in Pig Production}

\subsection{Usage of $\beta$-lactam Antibiotics and Emergence of Related AMR Determinants in Pig Production}

There are three usages of antibiotics in swine industries: (i) as growth promoters, (ii) as prophylactic or metaphylactic treatments, to prevent disease, and (iii) as therapeutics for the treatment of acute infections. Antimicrobial agents were introduced to treat diseases in food-producing animals in 1940s, and in 1950s feed supplemented with antimicrobials was already used for cattle, pigs and poultry [86]. Prophylactic (individual animal) and metaphylactic (whole herd) treatments also work by adding the antibiotic to the animal feed. However, the supplemented feed is used for a few days and not on a regular basis. The concentration of antibiotics is higher than in growth promotion uses and can reach therapeutic concentrations [87]. For therapeutic purposes there are a wide range of antibiotics available, and they can be used either orally or by injection. Antimicrobials used in clinical therapy are of broad spectrum and are mainly active against Gram-negative bacteria, like Salmonella or E. coli [86].

The use of growth promoters was banned by the EU in 2006, according to the EC Regulation No. 1831/2003 [88], but some of them were taken out of the market even before. Sweden was the first country in the world to ban the use of antibiotics in animal feed since 1986. However, antibiotics are still in use as growth promoters in some countries outside the EU. China has not yet prohibited the use of antibiotics as growth promoters, however they are proposing restrictions $[89,90]$, similar to the FDA in the USA.

In veterinary medicine, three groups of $\beta$-lactam antimicrobial agents are used, including penicillins, first- to fourth-generation cephalosporins and the $\beta$-lactamase inhibitors [6]. Regarding the penicillin type antibiotics, such as ampicillin, amoxicillin, benzylpenicillin, cloxacillin and hetacillin, they are used to treat infections caused by Gram-positive bacteria. They are commonly combined with $\beta$-lactamase inhibitors (e.g., amoxicillin-clavulanate) to prevent their degradation and inactivation [6]. First-generation cephalosporin antibiotics (cefadroxil, cefapirin and cephalexin) are administered as an alternative to treat staphylococcal and streptococcal infections. Second-generation cephalosporins (cefaclor, cefamandole, cefonicid, ceforanide and cefuroxime) have greater spectrum of activity against Gram-negative bacteria, while retaining some activity against Gram-positive bacteria. Cefovecin, cefpodoxime and ceftiofur, which are third generation cephalosporins, exhibit broad spectrum of activity and have increased activity against Gram-negative bacteria. Finally, fourth generation cephalosporins, such as cefquinome, which is used in veterinary medicine, have the broadest activity against Gram-negative as well as Gram-positive bacteria [6].

It has been shown that the use of specific antimicrobials, including third-generation cephalosporins (cefotaxime), strongly correlates with the level of resistance towards these antibiotics in commensal E. coli isolates from pigs [91,92]. Antibiotics used for growth promotion were initially from the same chemical families as the antibiotics used to treat human infections. They were added to the feed in low concentrations and for the whole life of the animal. This created the perfect environment for the selection of antibiotic resistant bacteria and the spread of ARGs among enteric bacteria in the pig gastrointestinal tract [87].

\subsection{Sales of Penicillins and Cephalosporins in the EU}

Based on FDA reports, Done and colleagues calculated that in the USA in 2011 around $80 \%$ of the antibiotics sold by weight were for animal usage [93].

The sales of penicillins, and first to fourth generation cephalosporins for food producing animals in the EU in 2017, according to the latest European Surveillance of Veterinary Antimicrobial Consumption (EVSAC) report on the sales of veterinary antimicrobial agents, are summed up in Table 2. Information on sales are calculated as $\mathrm{mg}$ of antimicrobial agent per population correction unit (PCU), that is a 
proxy for the size of the food-producing animal population [94]. Penicillin sales in the EU differed greatly, from $1.6 \mathrm{mg} / \mathrm{PCU}$ in Norway, up to $70.3 \mathrm{mg} / \mathrm{PCU}$ in Italy and $81.1 \mathrm{mg} / \mathrm{PCU}$ in Cyprus. The sales of first- and second-generation cephalosporins were lower than those of penicillins and third- and fourth-generation cephalosporins. No sales of first- and second-generation cephalosporins were reported in Iceland and Norway, while low sales $(0.01 \mathrm{mg} / \mathrm{PCU}$ or less) were registered in Sweden, Romania and Greece, and the highest sales were in Slovakia $(0.4 \mathrm{mg} / \mathrm{PCU})$. The sales of third and fourth generation cephalosporins within the EU were the highest in Estonia $(0.8 \mathrm{mg} / \mathrm{PCU})$, followed by Luxembourg and Portugal (both $0.6 \mathrm{mg} / \mathrm{PCU}$ ), and Czech Republic and Hungary (0.5 mg/PCU) [94]. Some countries, like Belgium, Bulgaria, Denmark, Finland, Iceland, Ireland, The Netherlands, Norway, Sweden and United Kingdom have low sales $(0.1 \mathrm{mg} / \mathrm{PCU}$ or less) of these antibiotics.

Table 2. Penicillin and cephalosporin sales in the EU for food-producing animals, in $\mathrm{mg}$ per population correction unit (mg/PCU) in 2017 [94].

\begin{tabular}{|c|c|c|c|c|}
\hline Region & Country & $\begin{array}{l}\text { Penicillin Sales for } \\
\text { Food-Producing Animals, } \\
(\mathrm{mg} / \mathrm{PCU}) \text { in } 2017\end{array}$ & $\begin{array}{l}\text { 1st- and 2nd-gen. } \\
\text { Cephalosporin Sales for } \\
\text { Food-Producing Animals, } \\
\text { (mg/PCU) in } 2017\end{array}$ & $\begin{array}{l}\text { 3rd- and 4th-gen. } \\
\text { Cephalosporin Sales for } \\
\text { Food-Producing Animals, } \\
\text { (mg/PCU) in } 2017\end{array}$ \\
\hline \multirow{10}{*}{ Northern Europe } & United Kingdom & 7.5 & 0.1 & 0.1 \\
\hline & Sweden & 7.7 & $<0.01$ & $<0.01$ \\
\hline & Finland & 8.8 & 0.03 & $<0.01$ \\
\hline & Latvia & 8.5 & 0.2 & 0.3 \\
\hline & Lithuania & 13.6 & 0.1 & 0.2 \\
\hline & Ireland & 9.7 & 0.3 & 0.1 \\
\hline & Estonia & 21.7 & 0.2 & 0.8 \\
\hline & Denmark & 11.9 & 0.02 & $<0.01$ \\
\hline & Iceland & 3.3 & 0 & $<0.01$ \\
\hline & Norway & 1.6 & 0 & $<0.01$ \\
\hline \multirow{7}{*}{ Western Europe } & Luxembourg & 6.8 & 0.1 & 0.6 \\
\hline & Netherlands & 12.6 & 0.04 & $<0.01$ \\
\hline & France & 9.3 & 0.2 & 0.02 \\
\hline & Germany & 34.5 & 0.1 & 0.4 \\
\hline & Belgium & 49.4 & 0.2 & 0.1 \\
\hline & Austria & 8.6 & 0.05 & 0.2 \\
\hline & Switzerland & 11.2 & 0.1 & 0.2 \\
\hline \multirow{7}{*}{ Eastern Europe } & Bulgaria & 24.7 & 0.02 & 0.1 \\
\hline & Czech Republic & 17.3 & 0.3 & 0.5 \\
\hline & Croatia & 22.3 & 0.2 & 0.2 \\
\hline & Hungary & 46.7 & 0.1 & 0.5 \\
\hline & Poland & 54.1 & 0.1 & 0.2 \\
\hline & Romania & 18.2 & $<0.01$ & 0.2 \\
\hline & Slovakia & 11.4 & 0.4 & 0.4 \\
\hline \multirow{8}{*}{ Southern Europe } & Cyprus & 81.1 & 0.03 & 0.4 \\
\hline & Spain & 58.5 & 0.03 & 0.2 \\
\hline & Greece & 18.6 & $<0.01$ & 0.1 \\
\hline & Italy & 70.3 & 0.2 & 0.4 \\
\hline & Malta & 12.1 & 0.1 & 0.2 \\
\hline & Portugal & 35.1 & 0.1 & 0.6 \\
\hline & Slovenia & 22.2 & 0.1 & 0.2 \\
\hline & Total & 23.2 & 0.1 & 0.3 \\
\hline
\end{tabular}

Overall, in sales of penicillins, third and fourth generation cephalosporins for food-producing animals were the lowest in Northern European countries. Both Eastern and Southern European countries have highest sales of third and fourth generation cephalosporins. At the same time, Southern 
European countries showed the lowest sales of first and second generation cephalosporins. It must be taken into consideration that these data are for all food-producing animals and not only for pigs.

\section{ESBL Producing E. coli in the Pork Production Chain}

With the intensive use of antimicrobials in veterinary medicine, the resistance levels against some antibiotics in food-producing animals have increased rapidly since the first reported cases of AMR. Animal farms and slaughterhouse wastewater treatment plants have been shown to contain a more diverse set of plasmids and gene cassettes, compared to hospital wastewater, and they might be considered a hotspot for horizontal ARG transfer [73]. In a study performed in Germany, an assessment of the prevalence of ESBL producing E. coli in slaughterhouses and municipal wastewater treatment plants was carried out and it showed that both the wastewaters from slaughterhouses $(85.1 \%)$ and municipal wastewater treatment plants $(97.2 \%)$ were highly contaminated with ESBL producing E. coli [82]. In fact, the personnel that works at abattoirs slaughtering, dehairing or eviscerating the animals, and the staff in municipal wastewater treatment plants, have a high risk of possible colonization by resistant (also ESBL-producing) bacteria [82]. Another route of transmission at farm level could be through the inhalation of the air or dust in the stables, which can carry ESBL producing bacteria [95].

\subsection{Prevalence of ESBL Producing E. coli in Fattening Pigs}

In 2012 EFSA gathered information on cefotaxime- and ceftazidime-resistant $E$. coli in fattening pigs from seven EU Member States (MS) and one non-MS that reported data, i.e., Denmark, The Netherlands, France, Belgium, Austria, Hungary, Poland, and Switzerland [96]. In 2015 and 2017 EFSA collected information about the prevalence of antimicrobial resistant $E$. coli as indicator bacteria isolated from fattening pigs and pork meat in the frame of the AMR routine monitoring program, according to Commission Implementation Decision 2013/652/EU [19]. In 2015, 28 EU Member States and two non-EU Member States (Norway and Switzerland) reported data on presumptive ESBL producing E. coli in fattening pigs [18]. In 2017, 31 countries participated in reporting the data to EFSA, 28 Member States and three other European countries (Norway, Iceland and Switzerland).

Among the participating countries in 2012, the highest prevalence of cefotaxime and ceftazidime resistant E. coli was reported in Belgium, $2.9 \%$ and 3.4\%, respectively, followed by Poland (2.6\%). No cefotaxime and ceftazidime resistant $E$. coli was reported in the Netherlands and Austria.

In 2017, the overall prevalence of presumptive ESBL producing E. coli in fattening pigs in the EU was 30.62\%, that is slightly higher than reported in 2015 (30.2\%) (Table 3) [19]. Overall, in Northern European countries, the prevalence of ESBL producing E. coli is lower than in other regions (Western, Eastern and Southern Europe). Latvia showed the highest prevalence rate both in 2017 (42.3\%) and 2015 (40\%) among Northern European countries, while Norway, Finland and Iceland had low prevalence rates $(0.7 \%$ to $0 \%)[18,19]$. Within Western European countries, in 2017, Belgium had the highest prevalence rate, while Switzerland and The Netherlands the lowest, with a $60.7 \%, 11.5 \%$ and $11 \%$ prevalence, respectively. Additionally, in 2015, the highest prevalence of ESBL producing E. coli was detected in Belgium (54.7\%), and the lowest in Switzerland (17\%) and The Netherlands $(10.3 \%)$. Interestingly, Belgium has the highest sales of penicillins, and first- and second-generation cephalosporins within the Western European countries.

With regards to Eastern European countries, in 2017, Hungary had the highest prevalence rate $(56.2 \%)$, while in 2015 Bulgaria was the country with the highest one $(49.8 \%)$. The lowest rates in 2017 were registered in the Czech Republic. In 2015 Slovakia had a prevalence of 9.1\%, while in 2017 it escalated to $34 \%$, which was the highest increase in all the EU. In addition, Slovakia had the highest sales of early generation cephalosporins within the EU. Southern Europe showed the highest prevalence of presumptive ESBL producing E. coli in fattening pigs, both in 2015 and 2017. Spain had the highest prevalence registered, both in 2015 (81.5\%) and in $2017(80.3 \%)$, and Cyprus the lowest, even though it had the highest sales of penicillins in the EU (Tables 2 and 3). 
Table 3. Prevalence of ESBL-producing, cefotaxime- and ceftazidime-resistant, E. coli isolates from fattening pigs and pork meat in the EU, 2012-2017. Adapted from [18,19,96].

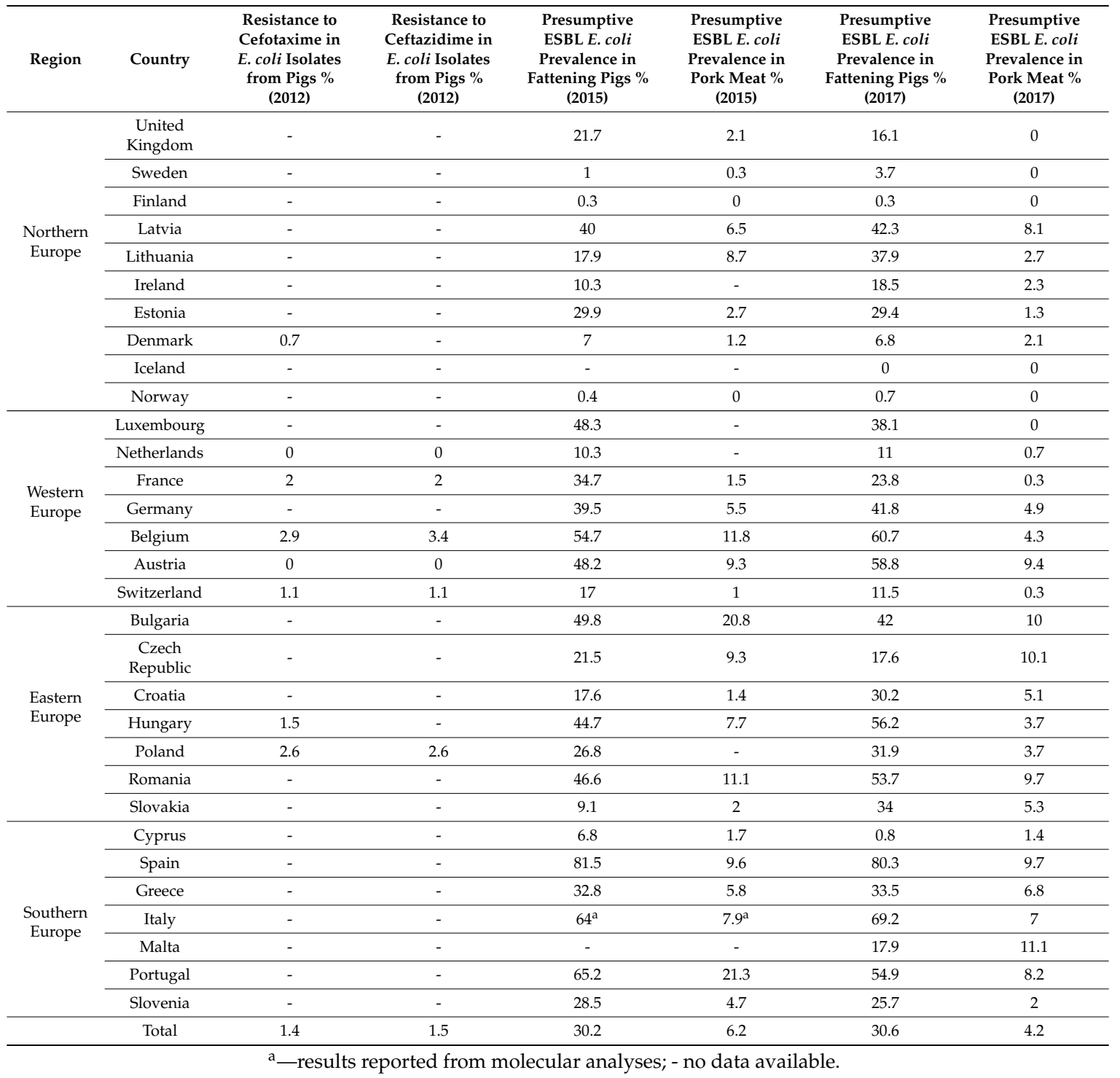

An increase in the prevalence of ESBL producing E. coli in fattening pigs has been reported in five out of eight countries (participating in reporting data since 2012). In The Netherlands, Belgium, Austria, Hungary and Poland, the prevalence of ESBL producing E. coli has increased dramatically. For example, in 2012 Austria reported 0\% prevalence of cefotaxime- or ceftazidime-resistant E. coli isolates from fattening pigs, while in 2015 the prevalence increased to $48.2 \%$, and in 2017 to $58.8 \%$. Similar increases have been reported by Belgium, where resistance to cefotaxime was $2.9 \%$ and to ceftazidime $3.4 \%$ in 2012, however in 2015 ESBL phenotypes were detected in $54.7 \%$ of the E. coli isolates from fattening pigs and in 2017 in 60.7\%. In Denmark, France and Switzerland, an increase from 2012 to 2015 was detected, but in 2017, the prevalence of ESBL producing E. coli decreased again.

In 2010, a voluntary ban on cephalosporin use in Danish pig production was approved in Denmark. After the ban (6-10 month period) the occurrence of extended-spectrum cephalosporinase (ESC)-producing E. coli in pigs at slaughterhouse decreased significantly, although ESC producing E. coli could still be detected in the herds for a period of time even after the cease of the use of third and fourth generation cephalosporins [97]. Likewise, a prevalence of ESBL-producing E. coli of 79\% has been reported on farms with high usage of cephalosporins, while on farms with no consumption of these antibiotics the prevalence was $20 \%$ [98]. These results indicate the presence of a direct 
correlation between the consumption of cephalosporins and the prevalence of ESBL-producing E. coli in pigs $[97,99]$.

The slaughter process of pigs includes many steps; some of them ensure the decrease of microbial contaminants, but some increase the risk of contamination. Thus, after scalding, singeing, carcass washing and rinsing steps, and chilling, the carcass microbial contamination and the numbers of Enterobacteriaceae decrease [100]. After scraping and polishing steps, re-contamination of pig carcasses can happen. Indeed, E. coli has been isolated from scraper/dry polisher blades prior to the start of the process [22]. The highest risk of Enterobacteriaceae contamination in the slaughterhouse and during meat processing is the evisceration step, as it includes the removal of intestines, which contain high amounts of E. coli.

Microbiological criteria aiming at improving the hygiene during slaughtering are set in the EU legislation (Regulation 2703/2005) [101]. According to the EU legislation, hot water can be used to reduce E. coli levels on pig's carcasses. However, other decontamination methods, apart from hot water, can be applied, if they have been previously evaluated and authorized for use [102]. At the same time, process water that accumulates in different phases of the slaughter process might be one of the possible cross-contamination routes during the slaughtering process [82].

\subsection{Prevalence of ESBL Producing E. coli in Pork Meat}

Pork meat is the most widely consumed meat worldwide. It accounts for more than $36 \%$ of the meat intake of the world, followed by poultry with a $35 \%$ and beef with a $22 \%$ [103]. The EU is the world's second largest pork producer after China, and exports around $13 \%$ of the produced meat [104]. The consumption of pork within the EU has increased in the last decade. The main pork meat producers in the EU are Germany, Spain and France and they generate half of the total EU production by number of animals [105].

In 2015, 23 EU Member States, Norway and Switzerland reported data on presumptive ESBL producing E. coli in pork meat [18]. The prevalence of ESBL-producing E. coli in pork meat was lower than in fattening pigs, and varied from $21.3 \%$ in Portugal and $20.8 \%$ in Bulgaria down to $0.3 \%$ in Sweden and $0 \%$ in Norway and Finland. In 2015 the overall prevalence of indicator E. coli with ESBL phenotypes in the EU Member states and Norway and Switzerland from pig caecum samples was $30.2 \%$, but from pork meat $6.2 \%$.

In 2017, 28 Member States and three other European countries (Norway, Iceland and Switzerland) reported data on presumptive ESBL producing E. coli in pork meat [19]. Prevalence in pork meat (gathered at retail) was lower than in 2015 and varied from 11.1\% in Malta down to $\%$ in Luxembourg, Sweden, Finland, United Kingdom, Iceland and Norway. In 2017 the overall prevalence of indicator E. coli with ESBL phenotypes in the EU Member states and Norway, Iceland and Switzerland from pig caecum samples was $30.6 \%$, but from pork meat $4.2 \%$ [19].

During a two-year (2015-2017) monitoring study, the prevalence of ESBL-producing E. coli in pork meat has decreased. The majority of countries show a decrease on prevalence of ESBL-producing E. coli in pork meat, with the largest decrease being reported by Portugal, from $21.3 \%$ down to $8.2 \%$. Nevertheless, eight countries reported increases; the highest increase was reported by Croatia, from $1.4 \%$ in 2015 to $5.1 \%$ in 2017.

As discussed in previous sections, many ESBL enzymes are encoded by genes located in plasmids and can be also found in bacteria from healthy animals, although resistance to some antibiotics such as ceftazidime and cefotaxime is higher among isolates from sick animals [106]. Food-producing animals, like poultry or pigs, carrying ESBL producing Enterobacteriaceae, even without showing any clinical signs of disease, are possible reservoirs of ESBLs that can be transferred to humans via the food chain by inappropriate handling and inadequate cooking of meat [71]. The transfer of commensal E. coli bacteria from animal intestines to meat can occur during the slaughter process. A study from Schill et al. showed that fresh pork meat can be a source of ESBLs, even though standard microbiological hygiene parameters were satisfactory [25]. ESBL-producing E. coli have been reported in meat products since 
1990s $[107,108]$. Generally, the ingestion of ESBL producing species does not result in the colonization or disease of the consumer. However, the exposure to these bacteria may facilitate the dissemination of ESBL genes to the human intestinal microbiome [86,109]. Indeed, it has been described that a plasmid from E. coli carrying the $b l a_{\mathrm{CTX}-\mathrm{M}-1}$ gene was transferred from pigs to piggery workers [110]. These transfer events pose a risk of colonization and spread of ESBLs in the human population.

Compared to 2015, in 2017 the prevalence of presumptive ESBL-producing E. coli in pig's caecum samples has increased in most EU countries. However, the contamination level in pork meat has decreased. It must be considered that in 2015 six countries were not included in the EFSA's report on antimicrobial resistance in zoonotic and indicator bacteria. The high prevalence of ESBLs in pigs and the relatively low prevalence in pork meat from official surveillance data demonstrates that animals carry ESBL-producing E. coli in their intestinal microbiota, but throughout the slaughter process carcasses are not heavily contaminated with the intestinal content and the ESBL-producing bacteria are somehow removed during the slaughtering and processing steps [19]. It must be taken into account that the prevalence of ESBL-producing E. coli in pigs is obtained from screenings performed from the caecum contents, which is a natural habitat of commensal E. coli, and not from swabs from the pig skin or other parts of the carcass, and this is likely the reason for the higher prevalence of ESBL-producing E. coli in pigs than in pork meat. As well, some countries have a high imported meat capacity, therefore, no direct relationship between the resistance in pig's caecum and pork meat can be performed [19].

Based on antibiotic sales data in 2017 and presumptive ESBL-producing E. coli prevalence in fattening pigs and in pork meat, the correlation level between the usage of $\beta$-lactam antibiotics and the resistance status of E. coli isolates has been characterized in the literature [111] ( Table 4; Table 5).

Table 4. Correlation between antibiotic sales and prevalence of presumptive ESBL-producing E. coli in fattening pigs, 2017.

\begin{tabular}{|c|c|c|c|c|}
\hline Antibiotic Sales & & Prevalence & $\begin{array}{l}\text { Correlation } \\
\text { Coefficient }\end{array}$ & Correlation Level [111] \\
\hline $\begin{array}{l}\text { Penicillin sales for } \\
\text { food-producing animals, } \\
\text { (mg/PCU) }\end{array}$ & $\&$ & $\begin{array}{l}\text { Presumptive } \\
\text { ESBL E. coli } \\
\text { prevalence in } \\
\text { fattening pigs }\end{array}$ & 0.464 & Middle \\
\hline $\begin{array}{c}\text { 1st and 2nd generation } \\
\text { cephalosporin sales for } \\
\text { food-producing animals, } \\
\text { (mg/PCU) }\end{array}$ & $\&$ & $\begin{array}{l}\text { Presumptive } \\
\text { ESBL E. coli } \\
\text { prevalence in } \\
\text { fattening pigs }\end{array}$ & 0.180 & Very low \\
\hline $\begin{array}{c}\text { 3rd and 4th generation } \\
\text { cephalosporin sales for } \\
\text { food-producing animals, } \\
\text { (mg/PCU) }\end{array}$ & $\&$ & $\begin{array}{l}\text { Presumptive } \\
\text { ESBL E. coli } \\
\text { prevalence in } \\
\text { fattening pigs }\end{array}$ & 0.074 & Very low \\
\hline
\end{tabular}

Table 5. Correlation between prevalence of presumptive ESBL E. coli in fattening pigs and pork meat.

\begin{tabular}{ccccc}
\hline Prevalence in Fattening Pigs & Prevalence in Pork & $\begin{array}{c}\text { Correlation } \\
\text { Meat }\end{array}$ & Coefficient & Correlation Level [111] \\
\hline $\begin{array}{c}\text { Presumptive ESBL E. coli prevalence } \\
\text { in fattening pigs in 2017 }\end{array}$ & $\& \quad \begin{array}{c}\text { Presumptive ESBL } \\
\text { E. coli prevalence in } \\
\text { pork meat in 2017 }\end{array}$ & 0.626 & Strong \\
\hline $\begin{array}{c}\text { Presumptive ESBL E. coli prevalence } \\
\text { in fattening pigs in 2015 }\end{array}$ & $\& \quad \begin{array}{c}\text { Presumptive ESBL } \\
\text { E. coli prevalence in } \\
\text { pork meat in 2015 }\end{array}$ & 0.735 & Strong \\
\hline
\end{tabular}

As indicated in Table 4, the correlation between the cephalosporin sales and the prevalence of presumptive ESBL E. coli in fattening pigs in 2017 was very low. However, a relevant correlation 
between sales of penicillins and the prevalence of presumptive ESBL E. coli in fattening pigs in 2017 was established (Figure 2). No official data on the sales of antibiotics are available for different food-producing animals, instead they are all summed up, therefore the results should be analyzed with precaution. A strong correlation was observed between the prevalence of presumptive ESBL producing E. coli in fattening pigs and in pork meat in 2017 and 2015 (Figure 3). Due to the lack of information on the prevalence of presumptive ESBL producing E. coli in fattening pigs or pork meat in 2015, six countries (Ireland, Iceland, Luxembourg, Netherlands, Poland and Malta) were excluded from the analyses.

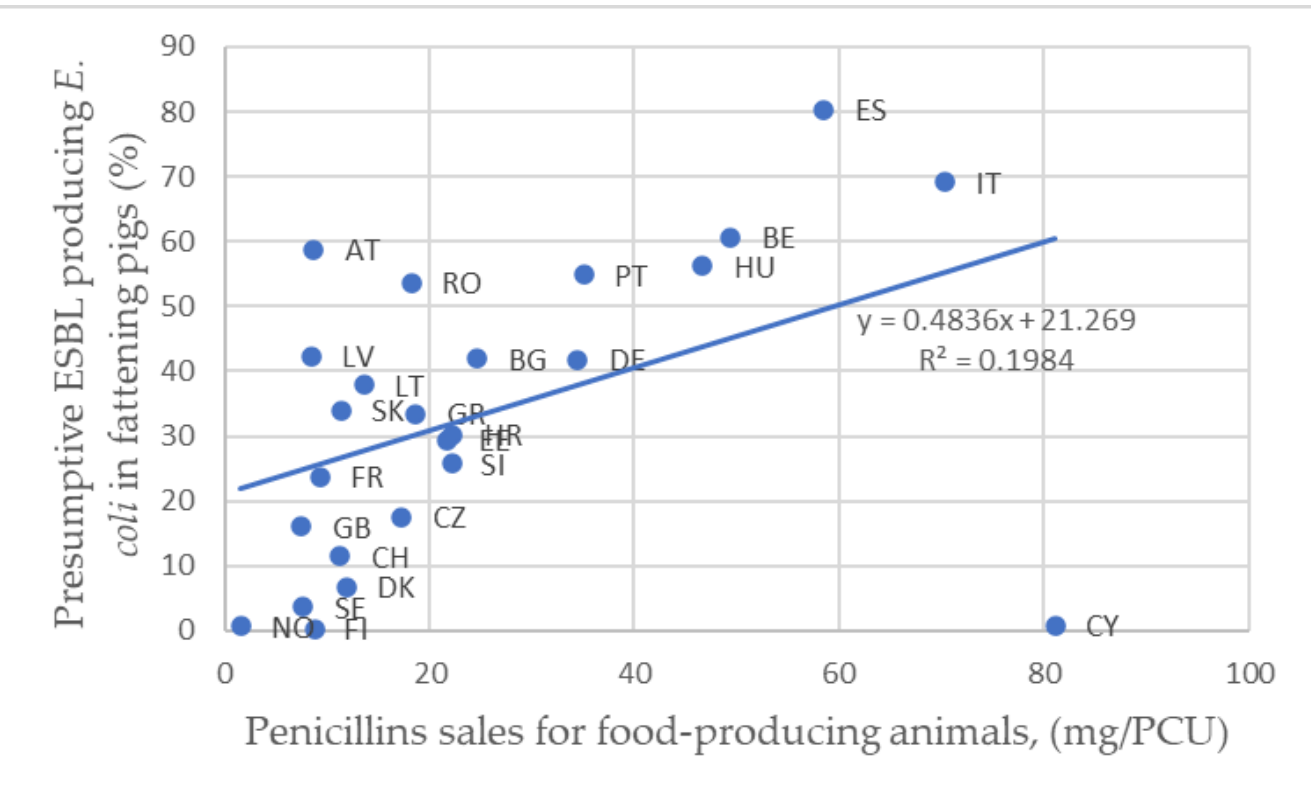

Figure 2. Correlation between presumptive ESBL E. coli prevalence in fattening pigs and sales of penicillins in 2017. Country codes used according to ISO 3166.

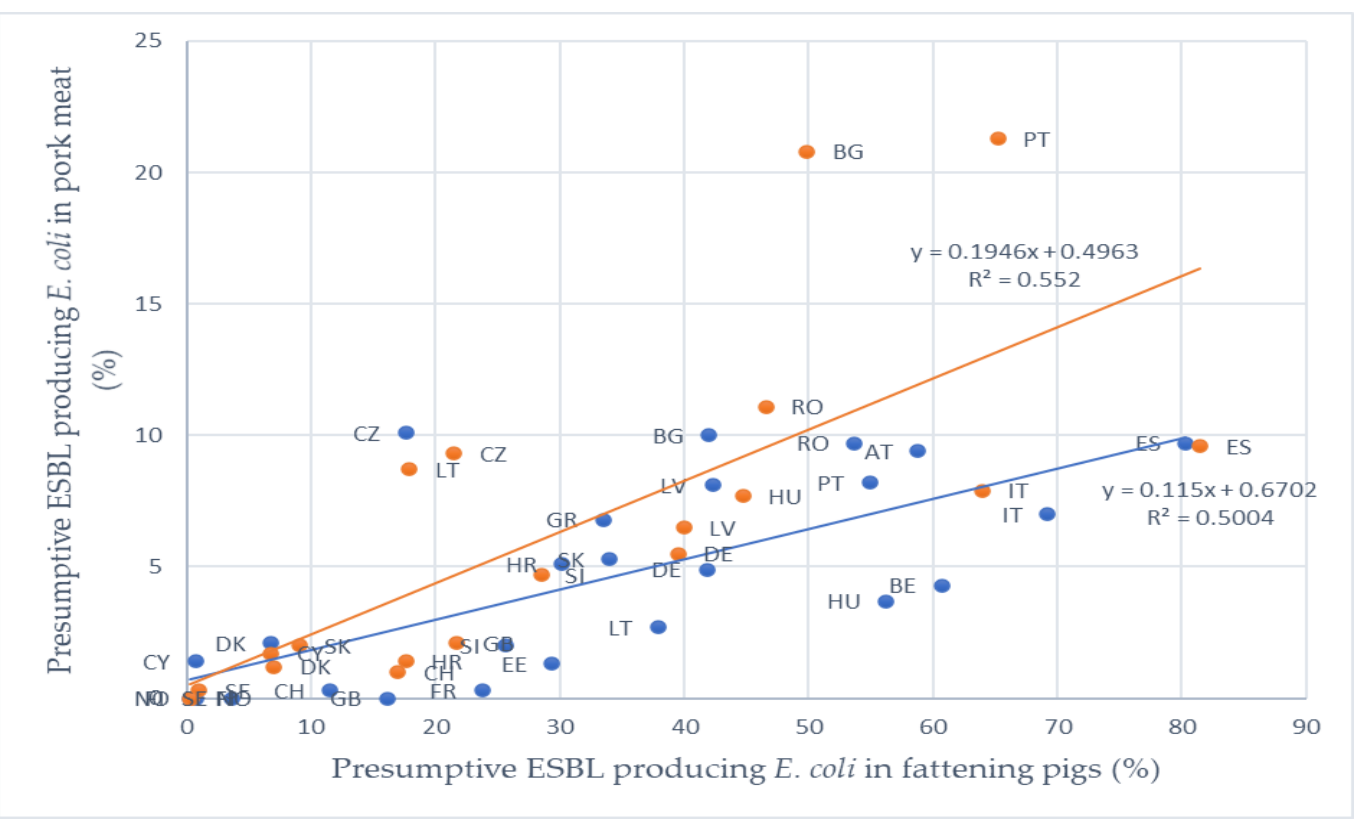

Figure 3. Correlation between the prevalence of presumptive ESBL producing E. coli in pork meat and in fattening pigs in 2015 (orange color) and 2017 (blue color). Country codes used according to ISO 3166. 


\section{Literature Review on the Prevalence of ESBL Producing E. coli in Pork Meat}

A literature search was conducted with the database Scopus using the search string (ESBL OR "extended spectrum $\beta$ lactamas" ${ }^{* \prime}$ ) AND (occurrence OR prevalence) AND (Escherichia OR coli OR "E. coli") AND (pork OR "ground pork" OR porcine OR "minced pork"). The literature search was limited to research articles published from 2000 to 2020 in the EU. The literature search was conducted until June 2020. In total, 902 articles were retrieved. A first screening was undertaken by revising titles and abstracts to remove articles not related to the topic. Then, for those articles which progressed to the next steps, the full text was analyzed to determine whether the inclusion criteria were met. Articles lacking information on the origin of the meat, the meat type, the number of screened samples, or the number/prevalence of positive isolates were discarded. At last, only 14 studies complied with the purpose of the review or were available. They are summarized in Table 6. The main purpose was to extract information on the prevalence of different ESBL producing E. coli in pork meat. However, different approaches were applied in these studies to determine the resistance status, e.g., isolate antimicrobial susceptibility determined by micro-broth dilution method using media supplemented with cefotaxime or ceftazidime, double synergy differential test, and sometimes confirmation by polymerase chain reaction (PCR) and DNA sequencing analyses. These studies examined both fresh and frozen pork meat from various parts of the carcass, with ground pork being also examined in some studies. Samples were taken from different meat production/retail places, such as slaughterhouses, supermarkets, butcher shops, meat-packaging, and meat-processing companies. Prevalence of ESBL producing E. coli varied from $0 \%$ up to $25 \%$. However, multiple factors must be considered, like the sample size, detection method used, and meat origin, therefore, the collected data should be analyzed with precaution. Interestingly, a large variability existed even among studies conducted in the same country. Thus, for instance, in Germany alone the prevalence rates largely varied, from $0.7 \%$ up to $17.5 \%$ [25,112]. 
Table 6. Prevalence of ESBL producing E. coli in pork meat, obtained from studies published in the EU.

\begin{tabular}{|c|c|c|c|c|c|c|c|c|c|}
\hline \multirow{2}{*}{ Meat Origin } & \multirow{2}{*}{$\begin{array}{l}\text { Sampling } \\
\text { Period }\end{array}$} & \multirow{2}{*}{ Type of Meat } & \multirow{2}{*}{ Meat Origin } & \multirow{2}{*}{$\begin{array}{l}\text { Number of } \\
\text { Samples }\end{array}$} & \multirow{2}{*}{$\begin{array}{c}\text { Prevalence of ESBL Producing } \\
\text { E. coli }(\%)\end{array}$} & \multicolumn{3}{|c|}{ ESBL Encoding Genes } & \multirow{2}{*}{ Reference } \\
\hline & & & & & & CTX-M (\%) & TEM (\%) & SHV (\%) & \\
\hline \multirow[b]{2}{*}{ Italy } & \multirow[b]{2}{*}{ 2016-2017 } & Carcasses & Slaughterhouse & 200 & 10 & 11.5 & 3.5 & 0.5 & \multirow[b]{2}{*}{ [114] } \\
\hline & & $\begin{array}{l}\text { Sausages, meat slices, } \\
\text { loin, salami dough, } \\
\text { cotechino, thighs for } \\
\text { ham production }\end{array}$ & Supermarkets & 446 & 2 & 1.8 & 1.4 & 0.2 & \\
\hline \multirow{4}{*}{ Belgium } & \multirow{4}{*}{ 2015-2016 } & Head & Slaughterhouse & 104 & 25 & - & - & - & \multirow{4}{*}{ [115] } \\
\hline & & Belly & Slaughterhouse & 104 & 7 & - & - & - & \\
\hline & & Ham & Slaughterhouse & 103 & 3 & - & - & - & \\
\hline & & Loin & Slaughterhouse & 104 & 1 & - & - & - & \\
\hline Germany & 2014 & Carcasses & Meat processing company & 63 & 17.5 & 15.9 & 4.8 & 0 & [25] \\
\hline Italy & 2013-2014 & Ground pork & Food market & 200 & 0 & - & - & - & [116] \\
\hline $\begin{array}{l}\text { England, } \\
\text { Wales, and } \\
\text { Scotland }\end{array}$ & 2013-2014 & Pork & $\begin{array}{l}\text { Supermarkets, discount store, convenience } \\
\text { stores, butchers }\end{array}$ & 79 & 3 & 2 & 0 & 0 & [117] \\
\hline Switzerland & 2013 & Pork & Meat-packaging plant & 50 & 0 & - & - & - & [118] \\
\hline \multirow{2}{*}{ Germany } & \multirow{2}{*}{ 2012-2013 } & Pork meat & \multirow{2}{*}{$\begin{array}{l}\text { Butcher shops, supermarkets, farmer's markets, } \\
\text { direct marketer, restaurants, canteens }\end{array}$} & 282 & 12.1 & 11.3 & 0.7 & 0.4 & \multirow{2}{*}{ [119] } \\
\hline & & Ground pork & & 214 & 13.6 & 10.7 & 0.9 & 0.9 & \\
\hline Poland & 2012-2013 & Pork & Slaughterhouse & 78 & 5 & 5.13 & 0 & 3.85 & [120] \\
\hline $\begin{array}{c}\text { Czech } \\
\text { Republic }\end{array}$ & 2012-2013 & Pork & Supermarkets & 110 & 3.1 & 0 & 40.6 & 0 & [113] \\
\hline Denmark & \multirow{4}{*}{ 2010-2011 } & \multirow{4}{*}{ Frozen or fresh pork } & \multirow{4}{*}{ Retail stores, outlets } & 44 & 2 & 2.3 & 2.3 & 0 & \multirow{4}{*}{ [121] } \\
\hline Germany & & & & 44 & 7 & 6.8 & 4.5 & 0 & \\
\hline Italy & & & & 20 & 15 & 10 & 10 & 0 & \\
\hline $\begin{array}{l}\text { Finland, The } \\
\text { Netherlands, } \\
\text { Poland, Spain }\end{array}$ & & & & 31 & 9.6 & 0 & 0 & 0 & \\
\hline Denmark & \multirow{3}{*}{2009} & \multirow{3}{*}{ Frozen or fresh pork } & \multirow{3}{*}{ Retail store, outlets } & 153 & 2 & 1.31 & 0 & 0 & \multirow{3}{*}{ [112] } \\
\hline Germany $^{\mathrm{a}}$ & & & & 142 & 0.7 & - & - & - & \\
\hline $\begin{array}{l}\text { The } \\
\text { Netherlands }\end{array}$ & & & & 16 & 0 & - & - & - & \\
\hline Austria & 2009 & Ground pork & Supermarkets & 27 & 3.7 & - & - & - & [122] \\
\hline Iceland & 2006-2007 & Pork & Meat-processing plants & 60 & 0 & - & - & - & [123] \\
\hline Spain & $2006-2007$ & Pork & Supermarket & 12 & 25 & - & - & - & [124] \\
\hline
\end{tabular}

${ }^{\mathrm{a}}$ no information on the gene/s present in the isolate; - not tested. 
In eight out of fourteen studies, ESBL coding genes were determined by PCR analysis. In all studies apart from the one conducted in the Czech Republic [113], CTX-M genes dominated. These findings agree with those of other studies before indicating that, nowadays, CTX-M is the most prevalent ESBL in livestock $[4,17]$. TEM $\beta$-lactamases were the second most prevalent type identified, with the highest rate $(40.6 \%)$ being detected in pork meat originating from the Czech Republic. SHV genes were present only in five studies with a relatively low prevalence rate, ranging from 0.2 to $3.85 \%$.

\section{Conclusions}

The prevalence of ESBL producing E. coli in the EU varies significantly among countries, both in fattening pigs (swine caecum samples) and pork meat. Different approaches regarding the use of antibiotics are applied in the EU. For instance, a voluntary ban on cephalosporins was adopted in Denmark in 2010 and since then the levels of ESBL producing E. coli isolated from pig caecum content have decreased. Overall, the prevalence of ESBL producing E. coli isolated from pigs is increasing over the years. The prevalence of presumptive ESBL producing E. coli in pork meat in the EU varies a lot, and even in countries where the prevalence is low or close to zero, it is possible that meat imported in the country from inside or outside the EU containing high levels of ESBL producing E. coli may pose a risk for the consumer. Some strategies to deal with the global AMR problem have been globally discussed and will in principle be also relevant in the fight against the spread of ESBL producing bacteria along the pork production chain. For example, good governance and usage principles of antimicrobials, monitoring of antimicrobial usage and resistance, and prevention measures, including biosecurity, should be implemented or revised to reduce the risk of introducing or spreading AMR bacteria into a herd or at farm level.

The personnel at swine industries (at farm level and slaughterhouses) are exposed to ESBL producing $E$. coli, which poses a risk of possible intestinal colonization with AMR pathogenic bacteria. Pork meat could be cross-contaminated during the slaughter process and by the personnel. Overall, the information available in the literature shows the urgent need to reconsider the responsible use of antimicrobials at farm level. Although the prevalence of ESBL producing E. coli is lower in pork meat than in pig caecum samples in most of the EU countries, pork meat can act as a transmission route for this group of critically important AMR bacteria. As pork meat can be cooked medium done and some pork products are not cooked, but fermented, it poses a risk of transferring the ESBL producing E. coli to the human gut microbiome upon consumption of contaminated meat. As E. coli is not a heat-resistant bacterium, it does not survive intense heat treatments. Therefore, appropriate cooking temperatures and times should be applied while preparing pork meat. Both in the pork production industry and in households, good hygiene practise should be followed.

Author Contributions: I.B. conducted the literature review and the original draft preparation. I.B., A.A.-O., M.P. and E.A.A. contributed to the interpretation of data, manuscript writing and revisions. G.K. reviewed the article and provided comments. All authors have read and agreed to the published version of the manuscript.

Funding: This research was funded by Ministry of Economy and Competitiveness, Government of Spain, grant number AGL2016-78085-P.

Acknowledgments: I.B. and G.K. are research fellows funded by the EU-FORA mobility program of the European Food Safety Authority.

Conflicts of Interest: The authors declare no conflict of interest.

\section{References}

1. WHO Antimicrobial Resistance. Available online: https://www.who.int/news-room/fact-sheets/detail/ antimicrobial-resistance (accessed on 22 June 2020).

2. Williams, K.J. The introduction of "chemotherapy" using arsphenamine-The first magic bullet. J. R. Soc. Med. 2009, 102, 343-348. [CrossRef]

3. Livermore, D.M.; Woodford, N. The $\beta$-lactamase threat in Enterobacteriaceae, Pseudomonas and Acinetobacter. Trends Microbiol. 2006, 14, 413-420. [CrossRef] [PubMed] 
4. Peirano, G.; Pitout, J.D.D. Extended-Spectrum $\beta$-Lactamase-Producing Enterobacteriaceae: Update on Molecular Epidemiology and Treatment Options. Drugs 2019, 79, 1529-1541. [CrossRef] [PubMed]

5. World Health Organisation. Prioritization of Pathogens to Guide Discovery, Research and Development of New Antibiotics for Drug-Resistant Bacterial Infections, including Tuberculosis; World Health Organisation: Geneva, Switzerland, 2017; pp. 1-88.

6. Smet, A.; Martel, A.; Persoons, D.; Dewulf, J.; Heyndrickx, M.; Herman, L.; Haesebrouck, F.; Butaye, P. Broad-spectrum $\beta$-lactamases among Enterobacteriaceae of animal origin: Molecular aspects, mobility and impact on public health. FEMS Microbiol. Rev. 2010, 34, 295-316. [CrossRef] [PubMed]

7. Abraham, E.P.; Chain, E. An Enzyme from Bacteria able to Destroy Penicillin. Nature 1940, $3713,837$. [CrossRef]

8. $\quad$ Pitout, J.D.D.; Laupland, K.B. Extended-spectrum $\beta$-lactamase-producing Enterobacteriaceae: An emerging public-health concern. Lancet Infect. Dis. 2010, 8, 159-166. [CrossRef]

9. Blair, J.M.A.; Webber, M.A.; Baylay, A.J.; Ogbolu, D.O.; Piddock, L.J.V. Molecular mechanisms of antibiotic resistance. Nat. Rev. Microbiol. 2015, 13, 42-51. [CrossRef] [PubMed]

10. Bradford, P.A. Extended-Spectrum-Lactamases in the 21st Century: Characterization, Epidemiology, and Detection of This Important Resistance Threat. Clin. Microbiol. Rev. 2001, 14, 933-951. [CrossRef]

11. Bush, K.; Bradford, P.A. Epidemiology of $\beta$-lactamase-producing pathogens. Clin. Microbiol. Rev. 2020, 33, 1-37. [CrossRef]

12. Ur Rahman, S.; Ali, T.; Ali, I.; Khan, N.A.; Han, B.; Gao, J. The Growing Genetic and Functional Diversity of Extended Spectrum Beta-Lactamases. Biomed. Res. Int. 2018, 2018. [CrossRef]

13. Medeiros, A.A. Evolution and Dissemination of $\beta$-Lactamases Accelerated by Generations of $\beta$-Lactam Antibiotics. Clin. Infect. Dis. 1997, 24, 19-45. [CrossRef] [PubMed]

14. Datta, N.; Kontomichalou, P. Penicillinase synthesis controlled by infectious R factors in Enterobacteriaceae. Nature 1965, 208, 239-241. [CrossRef] [PubMed]

15. Kliebe, C.; Nies, B.A.; Meyer, J.F.; Tolxdorff-Neutzling, R.M.; Wiedemann, B. Evolution of plasmid-coded resistance to broad-spectrum cephalosporins. Antimicrob. Agents Chemother. 1985, 28, 302-307. [CrossRef] [PubMed]

16. Sirot, D.; Sirot, J.; Labia, R.; Morand, A.; Courvalin, P.; Darfeuille-michaud, A.; Perroux, R.; Cluzel, R. Transferable resistance to third-generation cephalosporins in clinical isolates of klebsiella pneumoniae: Identification of CTX-1, a novel $\beta$-lactamase. J. Antimicrob. Chemother. 1987, 20, 323-334. [CrossRef]

17. Irrgang, A.; Hammerl, J.A.; Falgenhauer, L.; Guiral, E.; Schmoger, S.; Imirzalioglu, C.; Fischer, J.; Guerra, B.; Chakraborty, T.; Käsbohrer, A. Diversity of CTX-M-1-producing E. coli from German food samples and genetic diversity of the blaCTX-M-1 region on IncI1 ST3 plasmids. Vet. Microbiol. 2018, 221, 98-104. [CrossRef]

18. European Food Safety Authority; European Centre for Disease Prevention and Control. The European Union summary report on antimicrobial resistance in zoonotic and indicator bacteria from humans, animals and food in 2015. EFSA J. 2017, 15, e04694. [CrossRef]

19. European Food Safety Authority; European Centre for Disease Prevention and Control. The European union summary report on antimicrobial resistance in zoonotic and indicator bacteria from humans, animals and food in 2017. EFSA J. 2019, 17, 5598. [CrossRef]

20. Schmithausen, R.M.; Schulze-Geisthoevel, S.V.; Heinemann, C.; Bierbaum, G.; Exner, M.; Petersen, B.; Steinhoff-Wagner, J. Reservoirs and transmission pathways of resistant indicator bacteria in the Biotope pig stable and along the food chain: A review froma One Health Perspective. Sustainability 2018, 10, 3967. [CrossRef]

21. Wu, S.; Dalsgaard, A.; Vieira, A.R.; Emborg, H.D.; Jensen, L.B. Prevalence of tetracycline resistance and genotypic analysis of populations of Escherichia coli from animals, carcasses and cuts processed at a pig slaughterhouse. Int. J. Food Microbiol. 2009, 135, 254-259. [CrossRef]

22. Warriner, K.; Aldsworth, T.G.; Kaur, S.; Dodd, C.E.R. Cross-contamination of carcasses and equipment during pork processing. J. Appl. Microbiol. 2002, 93, 169-177. [CrossRef]

23. Ambler, R.P. The structure of $\beta$-lactamases. Phil. Trans. R. Soc. L. 1980, 289, 321-331. [CrossRef]

24. Bush, K.; Jacoby, G.A.; Medeiros, A.A. A functional classification scheme for $\beta$-lactamases and its correlation with molecular structure. Antimicrob. Agents Chemother. 1995, 39, 1211-1233. [CrossRef] [PubMed] 
25. Schill, F.; Abdulmawjood, A.; Klein, G.; Reich, F. Prevalence and characterization of extended-spectrum $\beta$-lactamase (ESBL) and AmpC $\beta$-lactamase producing Enterobacteriaceae in fresh pork meat at processing level in Germany. Int. J. Food Microbiol. 2017, 257, 58-66. [CrossRef] [PubMed]

26. Palzkill, T. Metallo- $\beta$-lactamase structure and function. Ann. N. Y. Acad. Sci. 2013, 1277, 91-104. [CrossRef] [PubMed]

27. Cantón, R. Epidemiology and Evolution of Beta-Lactamases. Evol. Biol. Bact. Fungal Pathog. 2008, $249-270$. [CrossRef]

28. Vahaboglu, H.; Öztürk, R.; Aygün, G.; Coşkunkan, F.; Yaman, A.; Kaygusuz, A.; Leblebicioglu, H.; Balik, I.; Aydin, K.; Otkun, M. Widespread detection of per-1-type extended-spectrum $\beta$-lactamases among nosocomial Acinetobacter and Pseudomonas aeruginosa isolates in Turkey: A nationwide multicenter study. Antimicrob. Agents Chemother. 1997, 41, 2265-2269. [CrossRef] [PubMed]

29. Matsumoto, Y.; Ikeda, F.; Kamimura, T.; Yokota, Y.; Mine, Y. Novel plasmid-mediated $\beta$-lactamase from Escherichia coli that inactivates oxyimino-cephalosporins. Antimicrob. Agents Chemother. 1988, 32, 1243-1246. [CrossRef]

30. Matsumoto, Y.; Inoue, M. Characterization of SFO-1, a plasmid-mediated inducible class A $\beta$ - lactamase from Enterobacter cloacae. Antimicrob. Agents Chemother. 1999, 43, 307-313. [CrossRef]

31. Poirel, L.; Le Thomas, I.; Naas, T.; Karim, A.; Nordmann, P. Biochemical sequence analyses of GES-1, a novel class A extended- spectrum $\beta$-lactamase, and the class 1 integron In52 from Klebsiella pneumoniae. Antimicrob. Agents Chemother. 2000, 44, 622-632. [CrossRef]

32. Rossolini, G.M.; Franceschini, N.; Lauretti, L.; Caravelli, B.; Riccio, M.L.; Galleni, M.; Frère, J.M.; Amicosante, G. Cloning of a Chryseobacterium (Flavobacterium) meningosepticum chromosomal gene (blaA(CME)) encoding an extended-spectrum class a $\beta$ - lactamase related to the Bacteroides cephalosporinases and the VEB-1 and PER $\beta$-lactamases. Antimicrob. Agents Chemother. 1999, 43, 2193-2199. [CrossRef]

33. Nordmann, P.; Ronco, E.; Naas, T.; Duport, C.; Michel-Briand, Y.; Labia, R. Characterization of a novel extended-spectrum $\beta$-lactamase from Pseudomonas aeruginosa. Antimicrob. Agents Chemother. 1993, 37, 962-969. [CrossRef] [PubMed]

34. Bonnet, R.; Sampaio, J.L.M.; Chanal, C.; Sirot, D.; De Champs, C.; Viallard, J.L.; Labia, R.; Sirot, J. A novel class A extended-spectrum $\beta$-lactamase (BES-1) in Serratia marcescens isolated in Brazil. Antimicrob. Agents Chemother. 2000, 44, 3061-3068. [CrossRef] [PubMed]

35. Silva, J.; Aguilar, C.; Ayala, G.; Estrada, M.A.; Garza-Ramos, A.; Lara-Lemus, R.; Ledezma, L. TLA-1 : A New Plasmid-Mediated Extended-Spectrum $\beta$-Lactamase from Escherichia coli. Antimicrob. Agents Chemother. 2000, 44, 997-1003. [CrossRef] [PubMed]

36. Danel, F.; Hall, L.M.C.; Gur, D.; Livermore, D.M. OXA-14, another extended-spectrum variant of OXA-10 (PSE-2) $\beta$-lactamase from Pseudomonas aeruginosa. Antimicrob. Agents Chemother. 1995, 39, 1881-1884. [CrossRef]

37. Danel, F.; Hall, L.M.C.; Gur, D.; Livermore, D.M. OXA-16, a further extended-spectrum variant of OXA-10 $\beta$-lactamase, from two Pseudomonas aeruginosa isolates. Antimicrob. Agents Chemother. 1998, 42, 3117-3122. [CrossRef]

38. Danel, F.; Hall, L.M.C.; Duke, B.; Gur, D.; Livermore, D.M. OXA-17, a further extended-spectrum variant of OXA-10 $\beta$-lactamase, isolated from Pseudomonas aeruginosa. Antimicrob. Agents Chemother. 1999, 43, 1362-1366. [CrossRef] [PubMed]

39. Mugnier, P.; Casin, I.; Bouthors, A.T.; Collatz, E. Novel OXA-10-derived extended-spectrum $\beta$-lactamases selected in vivo or in vitro. Antimicrob. Agents Chemother. 1998, 42, 3113-3116. [CrossRef]

40. Poirel, L.; Girlich, D.; Naas, T.; Nordmann, P. OXA-28, an extended-spectrum variant of OXA-10 $\beta$-lactamase from Pseudomonas aeruginosa and its plasmid- and integron-located gene. Antimicrob. Agents Chemother. 2001, 45, 447-453. [CrossRef]

41. Danel, F.; Hall, L.M.C.; Gur, D.; Livermore, D.M. OXA-15, an extended-spectrum variant of OXA-2 $\beta$-lactamase, isolated from a Pseudomonas aeruginosa strain. Antimicrob. Agents Chemother. 1997, 41, 785-790. [CrossRef]

42. Evans, B.A.; Amyes, S.G.B. OXA ß-lactamases. Clin. Microbiol. Rev. 2014, 27, 241-263. [CrossRef]

43. D'Andrea, M.M.; Arena, F.; Pallecchi, L.; Rossolini, G.M. CTX-M-type $\beta$-lactamases: A successful story of antibiotic resistance. Int. J. Med. Microbiol. 2013, 303, 305-317. [CrossRef] [PubMed] 
44. Bush, K.; Macielag, M.J. New $\beta$-lactam antibiotics and $\beta$-lactamase inhibitors. Expert Opin. Ther. Patents 2010, 20, 1277-1293. [CrossRef] [PubMed]

45. Pleiss, J. The Lactamase Engineering Database. Available online: http://www.laced.uni-stuttgart.de/ (accessed on 22 June 2020).

46. Clasen, J.; Birkegård, A.C.; Græsbøll, K.; Folkesson, A. Evolution of TEM-type extended-spectrum $\beta$-lactamases in Escherichia coli by cephalosporins. J. Glob. Antimicrob. Resist. 2019, 19, 32-39. [CrossRef] [PubMed]

47. Liakopoulos, A.; Mevius, D.; Ceccarelli, D. A review of SHV extended-spectrum $\beta$-lactamases: Neglected yet ubiquitous. Front. Microbiol. 2016, 7. [CrossRef] [PubMed]

48. Poirel, L.; He, C.; Podglajen, I.; Sougakoff, W.; Gutmann, L.; Nordmann, P. Emergence in Klebsiella pneumoniae of a Chromosome-Encoded SHV $\beta$-Lactamase That Compromises the Efficacy of Imipenem. Antimi 2003, 47, 755-758. [CrossRef]

49. Tzouvelekis, L.; Bonomo, R.A. SHV-type beta-lactamases. Curr Pharm Des. 1999, 5, 847-864.

50. Pitton, J.S. Mechanisms of Bacterial resistance to antibiotics. Rev. Physiol. 1972, 15-92.

51. Bauernfeind, A.; Stemplinger, I.; Jungwirth, R.; Ernst, S.; Casellas, J.M. Sequences of $\beta$-lactamase genes encoding CTX-M-1 (MEN-1) and CTX-M-2 and relationship of their amino acid sequences with those of other $\beta$-lactamases. Antimicrob. Agents Chemother. 1996, 40, 509-513. [CrossRef]

52. Gniadkowski, M.; Schneider, I.; Pałucha, A.; Jungwirth, R.; Mikiewicz, B.; Bauernfeind, A. Cefotaxime-resistant Enterobacteriaceae isolates from a hospital in Warsaw, Poland: Identification of a new CTX-M-3 cefotaxime-hydrolyzing $\beta$ - lactamase that is closely related to the CTX-M-1/MEN-1 enzyme. Antimicrob. Agents Chemother. 1998, 42, 827-832. [CrossRef]

53. Bonnet, R.; Sampaio, J.L.M.; Labia, R.; De Champs, C.; Sirot, D.; Chanal, C.; Sirot, J. A novel CTX-M $\beta$-lactamase (CTX-M-8) in cefotaxime-resistant Enterobacteriaceae isolated in Brazil. Antimicrob. Agents Chemother. 2000, 44, 1936-1942. [CrossRef]

54. Carattoli, A. Resistance plasmid families in Enterobacteriaceae. Antimicrob. Agents Chemother. 2009, 53, 2227-2238. [CrossRef] [PubMed]

55. Olson, A.B.; Silverman, M.; Boyd, D.A.; McGeer, A.; Willey, B.M.; Pong-Porter, V.; Daneman, N.; Mulvey, M.R. Identification of a progenitor of the CTX-M-9 group of extended-spectrum $\beta$-lactamases from Kluyvera georgiana isolated in Guyana. Antimicrob. Agents Chemother. 2005, 49, 2112-2115. [CrossRef] [PubMed]

56. Zhao, W.H.; Hu, Z.Q. Epidemiology and genetics of CTX-M extended-spectrum $\beta$-lactamases in Gram-negative bacteria. Crit. Rev. Microbiol. 2013, 39, 79-101. [CrossRef] [PubMed]

57. Lagacé-Wiens, P.R.S.; Tailor, F.; Simner, P.; DeCorby, M.; Karlowsky, J.A.; Walkty, A.; Hoban, D.J.; Zhanel, G.G. Activity of NXL104 in combination with $\beta$-lactams against genetically characterized Escherichia coli and Klebsiella pneumoniae isolates producing class A extended-spectrum $\beta$-lactamases and class $C \beta$-lactamases. Antimicrob. Agents Chemother. 2011, 55, 2434-2437. [CrossRef] [PubMed]

58. Bauernfeind, A.; Schweighart, S.; Grimm, H. A new plasmidic cefotaximase in a clinical isolate of Escherichia coli. Infection 1990, 18, 294-298. [CrossRef] [PubMed]

59. Bauernfeind, A.; Holley, M.; Jungwirth, R.; Mangold, P.; Röhnisch, T.; Schweighart, S.; Wilhelm, R.; Casellas, J.M.; Goldberg, M. A new plasmidic cefotaximase from patients infected with Salmonella typhimurium. Infection 1992, 20, 158-163. [CrossRef] [PubMed]

60. Hawkey, P.M.; Jones, A.M. The changing epidemiology of resistance. J. Antimicrob. Chemother. 2009, 64, i3-i10. [CrossRef] [PubMed]

61. Von Wintersdorff, C.J.H.; Penders, J.; Van Niekerk, J.M.; Mills, N.D.; Majumder, S.; Van Alphen, L.B.; Savelkoul, P.H.M.; Wolffs, P.F.G. Dissemination of antimicrobial resistance in microbial ecosystems through horizontal gene transfer. Front. Microbiol. 2016, 7, 173. [CrossRef]

62. Lenski, R.E. Experimental evolution and the dynamics of adaptation and genome evolution in microbial populations. ISME J. 2017, 11, 2181-2194. [CrossRef]

63. Norman, A.; Hansen, L.H.; Sørensen, S.J. Conjugative plasmids: Vessels of the communal gene pool. Philos. Trans. R. Soc. B Biol. Sci. 2009, 364, 2275-2289. [CrossRef]

64. Dhanji, H.; Khan, P.; Cottell, J.L.; Piddock, L.J.V.; Zhang, J.; Livermore, D.M.; Woodford, N. Dissemination of pCT-Like IncK plasmids harboring CTX-M-14 extended-spectrum $\beta$-lactamase among clinical Escherichia coli isolates in the United Kingdom. Antimicrob. Agents Chemother. 2012, 56, 3376-3377. [CrossRef] [PubMed] 
65. Rossolini, G.M.; D’Andrea, M.M.; Mugnaioli, C. The spread of CTX-M-type extended-spectrum $\beta$-lactamases. Clin. Microbiol. Infect. 2008, 14, 33-41. [CrossRef] [PubMed]

66. Toleman, M.A.; Bennett, P.M.; Walsh, T.R. ISCR Elements: Novel Gene-Capturing Systems of the 21st Century? Microbiol. Mol. Biol. Rev. 2006, 70, 296-316. [CrossRef]

67. Lartigue, M.F.; Poirel, L.; Aubert, D.; Nordmann, P. In vitro analysis of ISEcp1B-mediated mobilization of naturally occurring $\beta$-lactamase gene blaCTX-M of Kluyvera ascorbata. Antimicrob. Agents Chemother. 2006, 50, 1282-1286. [CrossRef] [PubMed]

68. Oliver, A.; Coque, T.M.; Alonso, D.; Valverde, A.; Baquero, F.; Cantón, R. CTX-M-10 linked to a Phage-Related Element is Widely Disseminated among Enterobacteriaceae in a Spanish Hospital. Antimicrob. Agents Chemother. 2005, 49, 1567-1571. [CrossRef] [PubMed]

69. Hall, R.M.; Collis, C.M. Mobile gene cassettes and integrons: Capture and spread of genes by site-specific recombination. Mol. Microbiol. 1995, 15, 593-600. [CrossRef] [PubMed]

70. Leverstein-van Hall, M.A.; Blok, H.E.M.; Donders, A.R.T.; Paauw, A.; Fluit, A.C.; Verhoef, J. Multidrug Resistance among Enterobacteriaceae Is Strongly Associated with the Presence of Integrons and Is Independent of Species or Isolate Origin. J. Infect. Dis. 2003, 187, 251-259. [CrossRef]

71. Carattoli, A. Animal reservoirs for extended spectrum $\beta$-lactamase producers. Clin. Microbiol. Infect. 2008, 14, 117-123. [CrossRef]

72. Poirel, L.; Bonnin, R.A.; Nordmann, P. Genetic support and diversity of acquired extended-spectrum $\beta$-lactamases in Gram-negative rods. Infect. Genet. Evol. 2012, 12, 883-893. [CrossRef]

73. Yuan, W.; Tian, T.; Yang, Q.; Riaz, L. Transfer potentials of antibiotic resistance genes in Escherichia spp. strains from different sources. Chemosphere 2020, 246, 125736. [CrossRef]

74. O'Brien, T.F. Emergence, Spread, and Environmental Effect of Antimicrobial Resistance: How Use of an Antimicrobial Anywhere Can Increase Resistance to Any Antimicrobial Anywhere Else. Clin. Infect. Dis. 2002, 34, S78-S84. [CrossRef] [PubMed]

75. Hernando-Amado, S.; Coque, T.M.; Baquero, F.; Martínez, J.L. Defining and combating antibiotic resistance from One Health and Global Health perspectives. Nat. Microbiol. 2019, 4, 1432-1442. [CrossRef] [PubMed]

76. Liu, C.M.; Stegger, M.; Aziz, M.; Johnson, T.J.; Waits, K.; Nordstrom, L.; Gauld, L.; Weaver, B.; Statham, S.; Horwinski, J.; et al. Escherichia coli ST131-H22 as a Foodborne Uropathogen. MBio 2018, 9. [CrossRef] [PubMed]

77. Rogers, B.A.; Sidjabat, H.E.; Paterson, D.L. Escherichia coli O25b-ST131: A pandemic, multiresistant, community-associated strain. J. Antimicrob. Chemother. 2011, 66, 1-14. [CrossRef]

78. Vieira, A.R.; Collignon, P.; Aarestrup, F.M.; McEwen, S.A.; Hendriksen, R.S.; Hald, T.; Wegener, H.C. Association between antimicrobial resistance in Escherichia coli isolates from food animals and blood stream isolates from humans in Europe: An ecological study. Foodborne Pathog. Dis. 2011, 8, 1295-1301. [CrossRef] [PubMed]

79. de Been, M.; Lanza, V.F.; de Toro, M.; Scharringa, J.; Dohmen, W.; Du, Y.; Hu, J.; Lei, Y.; Li, N.; Tooming-Klunderud, A.; et al. Dissemination of Cephalosporin Resistance Genes between Escherichia coli Strains from Farm Animals and Humans by Specific Plasmid Lineages. PLoS Genet. 2014, 10, e1004776. [CrossRef]

80. Madec, J.; Haenni, M.; Ponsin, C.; Kieffer, N.; Rion, E.; Gassilloud, B. Sequence Type 48 Escherichia coli Carrying the blaCTX-M-1 IncI1/ST3 Plasmid in Drinking Water in France. Antimicrob. Agents Chemother. 2016, 60, 6430-6432. [CrossRef] [PubMed]

81. Schijven, J.F.; Blaak, H.; Schets, F.M.; De Roda Husman, A.M. Fate of Extended-Spectrum $\beta$-Lactamase-Producing Escherichia coli from Faecal Sources in Surface Water and Probability of Human Exposure through Swimming. Environ. Sci. Technol. 2015, 49, 11825-11833. [CrossRef]

82. Savin, M.; Bierbaum, G.; Hammerl, J.A.; Heinemann, C.; Parcina, M.; Sib, E.; Voigt, A.; Kreyenschmidt, J. Antibiotic-resistant bacteria and antimicrobial residues in wastewater and process water from German pig slaughterhouses and their receiving municipal wastewater treatment plants. Sci. Total Environ. 2020, 727, 138788. [CrossRef]

83. Schmithausen, R.M.; Schulze-Geisthoevel, S.V.; Stemmer, F.; El-Jade, M.; Reif, M.; Hack, S.; Meilaender, A.; Montabauer, G.; Fimmers, R.; Parcina, M.; et al. Analysis of transmission of MRSA and ESBL-E among pigs and farm personnel. PLoS ONE 2015, 10, e0138173. [CrossRef] 
84. Oniciuc, E.A.; Likotrafiti, E.; Alvarez-Molina, A.; Prieto, M.; López, M.; Alvarez-Ordóñez, A. Food processing as a risk factor for antimicrobial resistance spread along the food chain. Curr. Opin. Food Sci. 2019, 30, 21-26. [CrossRef]

85. Lavilla, S.; González-López, J.J.; Miró, E.; Domínguez, A.; Llagostera, M.; Bartolomé, R.M.; Mirelis, B.; Navarro, F.; Prats, G. Dissemination of extended-spectrum $\beta$-lactamase-producing bacteria: The food-borne outbreak lesson. J. Antimicrob. Chemother. 2008, 61, 1244-1251. [CrossRef] [PubMed]

86. Hammerum, A.M.; Heuer, O.E. Human Health Hazards from Antimicrobial-Resistant Escherichia coli of Animal Origin. Clin. Infect. Dis. 2009, 48, 916-921. [CrossRef] [PubMed]

87. Barton, M.D. Impact of antibiotic use in the swine industry. Curr. Opin. Microbiol. 2014, 19, 9-15. [CrossRef]

88. European Parliament and the Council of the European Union. Regulation (EC) No 1831/2003 of the European Parliament and of the Council on additives for use in animal nutrition. Off. J. Eur. Union 2003, 4, $29-43$. Available online: http://eur-lex.europa.eu/legal-content/PT/TXT/?uri=celex:32003R1831 (accessed on 22 June 2020).

89. Xiao, Y. A National Action Plan to Contain Antimicrobial Resistance in China: Contents, Actions and Expectations. Available online: http://resistancecontrol.info/2017/a-national-action-plan-to-containantimicrobial-resistance-in-china-contents-actions-and-expectations/ (accessed on 23 July 2020).

90. Yang, H.; Paruch, L.; Chen, X.; van Eerde, A.; Skomedal, H.; Wang, Y.; Liu, D.; Clarke, J.L. Antibiotic application and resistance in swine production in China: Current situation and future perspectives. Front. Vet. Sci. 2019, 6, 136. [CrossRef]

91. Chantziaras, I.; Boyen, F.; Callens, B.; Dewulf, J. Correlation between veterinary antimicrobial use and antimicrobial resistance in food-producing animals: A report on seven countries. J. Antimicrob. Chemother. 2014, 69, 827-834. [CrossRef]

92. Fournier, C.; Aires-de-Sousa, M.; Nordmann, P.; Poirel, L. Occurrence of CTX-M-15- and MCR-1-producing Enterobacterales in pigs in Portugal: Evidence of direct links with antibiotic selective pressure. Int. J. Antimicrob. Agents 2020, 55, 105802. [CrossRef]

93. Done, H.Y.; Venkatesan, A.K.; Halden, R.U. Does the Recent Growth of Aquaculture Create Antibiotic Resistance Threats Different from those Associated with Land Animal Production in Agriculture? AAPS J. 2015, 17, 513-524. [CrossRef]

94. European Medicines Agency, European Surveillance of Veterinary Antimicrobial Consumption, 2019. Sales of Veterinary Antimicrobial Agents in 31 European Countries in 2017. Available online: https: //www.ema.europa.eu/en/documents/report/sales-veterinary-antimicrobial-agents-31-european-countries2017_en.pdf?elqTrackId=2383f3a8f966419299c3ce3b4258052f\&elq=65220e1bd1e34bcaa96b0addf44fdf3e\& elqaid $=28856 \&$ elqat $=1 \&$ elqCampaignId $=20867$ (accessed on 23 July 2020).

95. Dohmen, W.; Schmitt, H.; Bonten, M.; Heederik, D. Air exposure as a possible route for ESBL in pig farmers. Environ. Res. 2017, 155, 359-364. [CrossRef]

96. European Food Safety Authority; European Centre for Disease Prevention and Control. The European Union Summary Report on antimicrobial resistance in zoonotic and indicator bacteria from humans, animals and food in 2012. EFSA J. 2014, 12, 3590. [CrossRef]

97. AgersoØ, Y.; Aarestrup, F.M. Voluntary ban on cephalosporin use in Danish pig production has effectively reduced extended-spectrum cephalosporinase-producing Escherichia coli in slaughter pigs. J. Antimicrob. Chemother. 2013, 68, 569-572. [CrossRef] [PubMed]

98. Hammerum, A.M.; Larsen, J.; Andersen, V.D.; Lester, C.H.; Skytte, T.S.S.; Hansen, F.; Olsen, S.S.; Mordhorst, H.; Skov, R.L.; Aarestrup, F.M.; et al. Characterization of extended-spectrum $\beta$-lactamase (ESBL)-producing Escherichia coli obtained from Danish pigs, pig farmers and their families from farms with high or no consumption of third- or fourth-generation cephalosporins. J. Antimicrob. Chemother. 2014, 69, 2650-2657. [CrossRef] [PubMed]

99. Andersen, V.D.; Jensen, V.F.; Vigre, H.; Andreasen, M.; Agersø, Y. The use of third and fourth generation cephalosporins affects the occurrence of extended-spectrum cephalosporinase-producing Escherichia coli in Danish pig herds. Vet. J. 2015, 204, 345-350. [CrossRef] [PubMed]

100. Wheatley, P.; Giotis, E.S.; McKevitt, A.I. Effects of slaughtering operations on carcass contamination in an Irish pork production plant. Ir. Vet. J. 2014, 67, 1-6. [CrossRef]

101. European Commission. Commission Regulation (EC) No 2073/2005 on microbiological criteria for foodstuffs. Off. J. Eur. Union 2005, 338, 1-26. [CrossRef] 
102. Barco, L.; Belluco, S.; Roccato, A.; Ricci, A. Escherichia coli and Enterobacteriaceae counts on pig and ruminant carcasses along the slaughterline, factors influencing the counts and relationship between visual faecal contamination of carcasses and counts: A review. EFSA Support. Publ. 2014, 11, 634E. [CrossRef]

103. Food and Agriculture Organization of the United States. Animal Production and Health. Available online: http://www.fao.org/ag/againfo/themes/en/meat/backgr_sources.html (accessed on 22 June 2020).

104. European Commission. Information on Pork Production, Legal Bases, Market Monitoring, Trade, Carcass Classification, Price Reporting, Regulation of Supply of PDO/PGI Ham. Available online: https://ec.europa.eu/ info/food-farming-fisheries/animals-and-animal-products/animal-products/pork_en\#introduction (accessed on 22 June 2020).

105. European Commission. Pork Production up in the EU. 2017. Available online: https://ec.europa.eu/eurostat/ web/products-eurostat-news/-/DDN-20170919-1 (accessed on 22 June 2020).

106. Aasmäe, B.; Häkkinen, L.; Kaart, T.; Kalmus, P. Antimicrobial resistance of Escherichia coli and Enterococcus spp. isolated from Estonian cattle and swine from 2010 to 2015. Acta Vet. Scand. 2019, 61, 5. [CrossRef]

107. Kojima, A.; Ishii, Y.; Ishihara, K.; Esaki, H.; Asai, T.; Oda, C.; Tamura, Y.; Yamaguchi, K. Extended-SpectrumLactamase-Producing. Antimicrob. Agents Chemother. 2005, 49, 3533-3537. [CrossRef]

108. Zhao, S.; White, D.G.; Mcdermott, P.F.; Friedman, S.; English, L.; Ayers, S.; Meng, J.; Maurer, J.J.; Holland, R.; Walker, R.D. Identifcation and Expression of Cephamycinase blaCMY Genes in Escherichia coli and Salmonella Isolates from Food Animals and Ground Meat. Antimicrob. Agents Chemother. 2001, 45, 3647-3650. [CrossRef]

109. van Hoek, A.H.A.M.; Veenman, C.; van Overbeek, W.M.; Lynch, G.; de Roda Husman, A.M.; Blaak, H. Prevalence and characterization of ESBL- and AmpC-producing Enterobacteriaceae on retail vegetables. Int. J. Food Microbiol. 2015, 204, 1-8. [CrossRef] [PubMed]

110. Moodley, A.; Guardabassi, L. Transmission of IncN plasmids carrying blaCTX-M-1 between commensal escherichia coli in pigs and farm workers. Antimicrob. Agents Chemother. 2009, 53, 1709-1711. [CrossRef] [PubMed]

111. Dahliani, E.R.; Rahmatan, H. Djufri The correlation between students' interest and learning outcomes in biology. J. Phys. Conf. Ser. 2020, 1460, 1-6. [CrossRef]

112. Agersø, Y.; Aarestrup, F.M.; Pedersen, K.; Seyfarth, A.M.; Struve, T.; Hasman, H. Prevalence of extended-spectrum cephalosporinase (ESC)-producing Escherichia coli in Danish slaughter pigs and retail meat identified by selective enrichment and association with cephalosporin usage. J. Antimicrob. Chemother. 2012, 67, 582-588. [CrossRef]

113. Skočková, A.; Koláčková, I.; Bogdanovičová, K.; Karpíšková, R. Characteristic and antimicrobial resistance in Escherichia coli from retail meats purchased in the Czech Republic. Food Control. 2015, 47, 401-406. [CrossRef]

114. Barilli, E.; Vismarra, A.; Villa, Z.; Bonilauri, P.; Bacci, C. ES $\beta L$ E. coli isolated in pig's chain: Genetic analysis associated to the phenotype and biofilm synthesis evaluation. Int. J. Food Microbiol. 2019, 289, 162-167. [CrossRef]

115. Biasino, W.; De Zutter, L.; Garcia-Graells, C.; Uyttendaele, M.; Botteldoorn, N.; Gowda, T.; Van Damme, I. Quantification, distribution and diversity of ESBL/AmpC-producing Escherichia coli on freshly slaughtered pig carcasses. Int. J. Food Microbiol. 2018, 281, 32-35. [CrossRef]

116. Sabia, C.; Stefani, S.; Messi, P.; de Niederhäusern, S.; Bondi, M.; Condò, C.; Iseppi, R.; Anacarso, I. Extended-Spectrum B-Lactamase and Plasmid-Mediated AMPC Genes in Swine and Ground Pork. J. Food Saf. 2017, 37, e12282. [CrossRef]

117. Randall, L.P.; Lodge, M.P.; Elviss, N.C.; Lemma, F.L.; Hopkins, K.L.; Teale, C.J.; Woodford, N. Evaluation of meat, fruit and vegetables from retail stores in five United Kingdom regions as sources of extended-spectrum beta-lactamase (ESBL)-producing and carbapenem-resistant Escherichia coli. Int. J. Food Microbiol. 2017, 241, 283-290. [CrossRef]

118. Vogt, D.; Overesch, G.; Endimiani, A.; Collaud, A.; Thomann, A.; Perreten, V. Occurrence and genetic characteristics of third-generation cephalosporin-resistant Escherichia coli in Swiss retail meat. Microb. Drug Resist. 2014, 20, 485-494. [CrossRef]

119. Kaesbohrer, A.; Bakran-Lebl, K.; Irrgang, A.; Fischer, J.; Kämpf, P.; Schiffmann, A.; Werckenthin, C.; Busch, M.; Kreienbrock, L.; Hille, K. Diversity in prevalence and characteristics of ESBL/pAmpC producing E. coli in food in Germany. Vet. Microbiol. 2019, 233, 52-60. [CrossRef] [PubMed] 
120. Wasiński, B.; Rózanska, H.; Osek, J. Occurrence of extended spectrum B-Lactamaseand AmpC-Producing Escherichia coli in meat samples. Bull. Vet. Inst. Pulawy 2013, 57, 513-517. [CrossRef]

121. Egervärn, M.; Börjesson, S.; Byfors, S.; Finn, M.; Kaipe, C.; Englund, S.; Lindblad, M. Escherichia coli with extended-spectrum beta-lactamases or transferable AmpC beta-lactamases and Salmonella on meat imported into Sweden. Int. J. Food Microbiol. 2014, 171, 8-14. [CrossRef] [PubMed]

122. Springer, B.; Bruckner, K. Characterization of extended-spectrum beta-lactamase (ESBL) producing Escherichia coli from raw meat and comparison to human isolates. Wien. Tierarztl Monatsschr 2012, $99,44-50$.

123. Thorsteinsdottir, T.R.; Haraldsson, G.; Fridriksdottir, V.; Kristinsson, K.G.; Gunnarsson, E. Prevalence and genetic relatedness of antimicrobial-resistant escherichia coli isolated from animals, foods and humans in Iceland. Zoonoses Public Health 2010, 57, 189-196. [CrossRef]

124. Paterson, D.L.; Egea, P.; Pascual, A.; López-Cerero, L.; Navarro, M.D.; Adams-Haduch, J.M.; Qureshi, Z.A.; Sidjabat, H.E.; Rodríguez-Baño, J. Extended-spectrum and CMY-type $\beta$-lactamase-producing Escherichia coli in clinical samples and retail meat from Pittsburgh, USA and Seville, Spain. Clin. Microbiol. Infect. 2010, 16, 33-38.

(C) 2020 by the authors. Licensee MDPI, Basel, Switzerland. This article is an open access article distributed under the terms and conditions of the Creative Commons Attribution (CC BY) license (http://creativecommons.org/licenses/by/4.0/). 